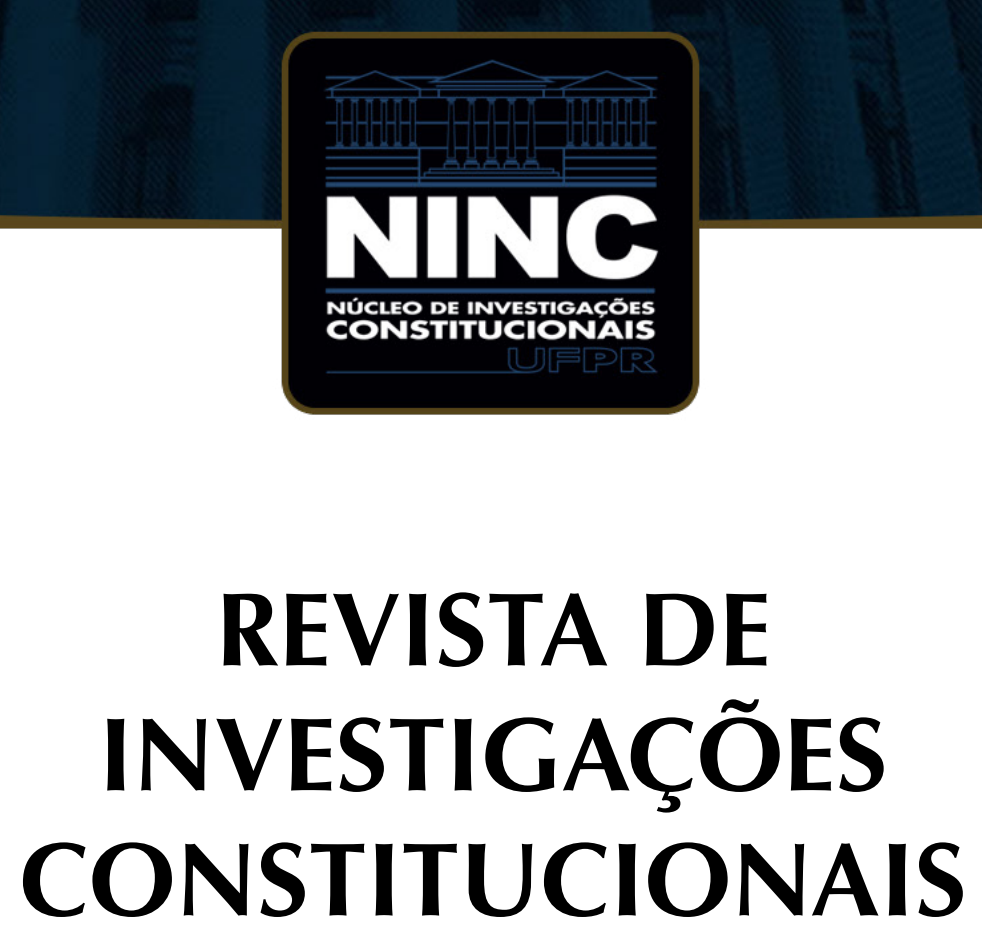

vol. 4 | n. 1 | janeiro/abril 2017 | ISSN 2359-5639 | Periodicidade quadrimestral Curitiba | Núcleo de Investigações Constitucionais da UFPR | www.ninc.com.br 


\section{Desafios contemporâneos da justiça administrativa na América Latina*}

\section{Contemporary challenges in Latin American administrative justice}

\section{RICARDO PERLINGEIRO**}

Universidade Federal Fluminense (Brasil) ricardoperlingeiro@id.uff.br

Recebido/Received: 12.01.2017 / January 12th, 2017 Aprovado/Approved: 06.02.2017 / February 6th, 2017

\section{Resumo}

O presente estudo consiste em uma análise crítica comparada dos sistemas de jurisdição administrativa nos 18 países latino-americanos de origem ibérica, sujeitos à Convenção Americana de Direitos Humanos (Argentina, Bolívia, Brasil, Chile, Colômbia, Costa Rica, El Salvador Equador, Guatemala, Honduras, México, Nicarágua, Panamá, Paraguai, Peru, República Dominicana, Uruguai e Venezuela). Como fator de estrangulamento da efetividade da jurisdição administrativa, o excesso de litígios nos tribunais latino-americanos é associado a uma indevida adaptação do sistema judiciário único, típico do direito administrativo de países vinculados ao common law,

\section{Abstract}

his study consists of a critical comparative analysis of the administrative justice systems in eighteen Latin-American signatory countries of the American Convention on Human Rights (Argentina, Bolivia, Brazil, Chile, Colombia, Costa Rica, El Salvador, Ecuador, Guatemala, Honduras, Mexico, Nicaragua, Panama, Paraguay, Peru, the Dominican Republic, Uruguay and Venezuela). According to this article, the excessive litigation in Latin-American courts that has seriously hampered the effectiveness of the administrative justice systems may be explained as follows: as former Iberian colonies, the aforementioned countries have a Continental European legal culture (civil law) but nevertheless have

Como citar esse artigo/How to cite this article: PERLINGEIRO, Ricardo. Desafios contemporâneos da justiça administrativa na América Latina. Revista de Investigações Constitucionais, Curitiba, vol.4, n. 1, p. 167-205, jan./abr. 2017.DOI: 10.5380/rinc.v4i1.50155

* Texto-base da conferência Reform of Administrative Justice in Latin America, ministrada no Seminário internacional Administrative justice: comparative and Russian contexts, em Tyumen, República Federativa da Rússia, nos dias 29 e 30 de setembro de 2016, no âmbito do II Fórum Jurídico Siberiano destinado ao Direito Processual Administrativo Russo. As teses apresentadas neste artigo decorrem de estudos iniciados quando da conferência ministrada no Seminário Perspectivas comparativas de la Justicia Administrativa, organizado pelo Centro de Investigación y Docencia Económica (CIDE), na Cidade do México, em 7 de fevereiro de 2014, e cujo conteúdo levou às seguintes publicações: O devido processo administrativo e a tutela judicial efetiva: um novo olhar?, na Revista de Processo, São Paulo, v. 239, p. 293-331, jan. 2015, e Justiça administrativa no Brasil: uma jurisdição administrativa judicial, extrajudicial ou híbrida?, na Revista CEJ, Brasília, Ano XVIII, n. 62, p. 71-78, jan./abril 2014. Agradecimentos a Alexandre Arruda, Bernard Reis, Carmen Silvia Arruda e Flavia Martins Affonso, doutorandos em direito na Universidade Federal Fluminense (UFF), e Graziela De Caro e Anna Gabriela Costa, graduandas em direito na mesma universidade, e Juliana Perlingeiro, da Universidade Federal do Rio de Janeiro (UFRJ).

** Professor Titular da Faculdade de Direito da Universidade Federal Fluminense (Niterói-RJ, Brasil). Doutor e Mestre em Direito pela Universidade Gama Filho (Rio de Janeiro - Rio de Janeiro, Brasil). Pesquisador convidado do Deutsches Forschungsinstitut für öffentliche Verwaltung Speyer - FÖV (Speyer, Alemanha) (2006-2007). Coordenador brasileiro do Projeto DAAD Justiça Administrativa e fortalecimento do Estado de Direito na América Latina (2009-2012). Desembargador Federal do Tribunal Regional Federal da 2a Região (Rio de Janeiro, Brasil). E-mail: ricardoperlingeiro@id.uff.br. 
em uma cultura jurídica europeia-continental com origem no civil law. Tal cenário, segundo o autor, pode ser revertido mediante o fortalecimento do papel das autoridades administrativas quanto a funções jurisdicionais e a funções meramente executivas, dotando-lhes de prerrogativas que assegurem uma atuação (independente $e$ imparcial) orientada pela supremacia dos direitos fundamentais, e com lastro na doutrina do controle difuso de convencionalidade consagrada pela Corte Interamericana de Direitos Humanos.

Palavras-chave: justiça administrativa; devido processo legal; processo administrativo; jurisdição; América Latina. improperly integrated certain aspects of the unified judicial system (generalized courts) typical of administrative law in common law countries. This situation, according to the author, could be rectified through strengthening the public administrative authorities with respect to their dispute-resolution and purely executive functions by endowing them with prerogatives to act independently and impartially, oriented by the principle of legality understood in the sense of supremacy of fundamental rights, in light of the doctrine of diffuse conventionality control adopted by the Inter-American Court of Human Rights.

Keywords: administrative justice; due process; administrative process; adjudication; Latin America.

\section{SUMÁRIO}

1. Introdução; 2. Direito à tutela judicial efetiva; 2.1. Intensidade; 2.1.1. Controle sobre o conteúdo das decisões administrativas; 2.1.2. Controle jurisdicional de atos de governo; 2.2. Pretensões admissíveis; 2.3. Medidas cautelares; 2.4. Judicialização exacerbada; 3. Desafios referentes ao sistema judiciário; 3.1. Razões históricas da crise de identidade do sistema judicial; 3.2. Os extremos: deferência administrativa e controle judicial intenso; 3.3. Credibilidade a partir da especialização dos tribunais; 3.4. Individuais as demandas repetitivas?; 4. Desafios referentes às autoridades administrativas; 4.1. Funções administrativas primárias; 4.2. Funções administrativas secundárias; 5. Controle difuso de convencionalidade pelas autoridades administrativas; $\mathbf{6}$. Certas perspectivas organizacionais para a jurisdição administrativa; 7. Considerações finais; 8. Referências.

\section{INTRODUÇÃO}

O excesso de demandas judiciais na América Latina é extraordinário e poderia deixar um visitante perplexo com a alta produtividade dos seus tribunais judiciais. A título de exemplo, no Brasil, somente em 2014, cada juiz proferiu em média 1500 sentenças. ${ }^{1}$

Contudo, em matéria de direito administrativo, na realidade, os juízes vêm sendo induzidos a decidir questões análogas, repetidas, o que os têm aproximado da figura de um gestor de acervos processuais e de uma autoridade meramente executiva, ${ }^{2} \mathrm{e}$

\footnotetext{
1 CONSELHO NACIONAL DE JUSTIÇA. Justiça em números: ano base 2013. Brasília: CNJ, 2014. p. 39. Ver também: CONSELHO NACIONAL DE JUSTIÇA. Justiça em números: ano base 2014. Brasília: CNJ, 2015. Sobre o excesso de demandas judiciais no contencioso administrativo chileno, ver: CORTE SUPREMA DO CHILE. Acta 176, de 24 de outubro de 2014

2 Ver: REIS, Wanderlei José dos. Juiz-Gestor: um novo paradigma. Revista On Line do Instituto Brasileiro de Administração do Sistema Judiciário - IBRAJUS, [S.I.] 2011. Disponível em: < http://www.ibrajus.org.br/ revista/artigo.asp?idArtigo=215>.; SILVEIRA NETO, Antônio. Conflitos de massa e gestão dos processos judiciais. In: MORAES, Vânila Cardoso A. de (Coord.). As demandas repetitivas e os grandes litigantes. Brasília: Enfam, 2016; e GUBERT, Jerson Moacir; BORDASCH, Rosane Wanner Silva. Processamento e Gestão das Ações
} 
com o sacrifício da sua vocação jurisdicional para decidir conflitos e proteger direitos. ${ }^{3}$ Isso porque, a maioria dos litígios é artificial, ou seja, não decorre de uma pretensão cujo atendimento esteja ao alcance das autoridades, mas resulta de uma realidade em que tais autoridades não cumprem seus deveres por falta de infraestrutura suficiente para harmonizar o princípio da legalidade (associado à supremacia dos direitos fundamentais) com o princípio administrativo da subordinação hierárquica. ${ }^{4}$ Ademais, em muitos casos, são as autoridades que buscam o Judiciário com pretensões executórias contra particulares, externando o consenso (entre cidadãos, autoridades, Judiciário e legislador) de que autoridades administrativas não são confiáveis para promover a execução das suas próprias decisões, em flagrante contradição com o poder de autoexecutoriedade dos atos administrativos. 5

Com efeito, observa-se um formidável avanço dos princípios processuais inerentes à tutela judicial efetiva na legislação e jurisprudência latino-americanas. No entanto, por diversas razões, que vão desde a ausência de especialização do Judiciário e de leis processuais sensíveis à natureza de direito público dos conflitos até a ausência de independência e de capacidade técnica das autoridades administrativas para exercerem o seu papel institucional, o fato é que não se consegue estancar a proliferação de demandas repetitivas ora rotuladas de "demandas artificiais".6 Segundo Falcão, "A bolha judicial cresce, e a confiança na Justiça diminui".7

Nesse contexto, em busca de soluções para o aperfeiçoamento da jurisdição administrativa na América Latina, aborda-se o atual estágio de evolução do direito à proteção judicial sobre as causas de direito administrativo, em paralelo com a organização judiciária correspondente, sem perder de vista as funções executivas e também jurisdicionais a cargo das autoridades administrativas. Para tanto, realizou-se uma análise crítica e comparada dos sistemas de justiça administrativa dos países latino-americanos de origem ibérica e sujeitos à Convenção Americana de Direitos Humanos: Argentina, Bolívia, Brasil, Chile, Colômbia, Costa Rica, El Salvador, Equador, Guatemala,

de Massa. In: MORAES, Vânila Cardoso A. de (Coord.). As demandas repetitivas e os grandes litigantes. Brasília: Enfam, 2016.

3 Ver STRECK, Lenio Luiz. Juiz não é gestor nem gerente. Ele deve julgar. E bem! Consultor Jurídico, São Paulo, ago. 2013. Disponível em: < http://www.conjur.com.br/2013-ago-08/senso-incomum-juiz-nao-gestor-nem-gerente-juiz-julgar-bem>. Acesso em: 31 jan 2017.

4 Ver o tópico 3 deste artigo em diante.

5 Ver PERLINGEIRO, Ricardo. A execução forçada de pretensões pecuniárias e a coerção administrativa de fazer, suportar ou omitir-se. Revista de Direito Administrativo Contemporâneo, São Paulo, v. 21, ano 3, p. $133-141$. 2015.

6 Demandas repetitivas é uma expressão adotada pelo Conselho Nacional de Justiça brasileiro, no projeto Pesquisa sobre Demandas Repetitivas, e no art. 976 do Código de Processo Civil brasileiro, com o Incidente de Deandas Repetitivas.

7 FALCÃO, Joaquim. A bolha judicial. Revista Conjuntura Econômica, Rio de Janeiro, v. 60, n. 4, p. 45, abr. 2006. 
Honduras, México, Nicarágua, Panamá, Paraguai, Peru, República Dominicana, Uruguai e Venezuela.

Como fonte de pesquisa, o estudo incluiu a jurisprudência da Corte Interamericana de Direitos Humanos (Corte I.D.H.) e de tribunais nacionais; a legislação processual nacional (Judicial e Extrajudicial); o Código Modelo de Processos (Judicial e Extrajudicial) para Ibero-América, do Instituto Ibero-Americano de Direito Processual;8 o Código Modelo Euro-Americano de Jurisdição Administrativa, da Universidade Federal Fluminense e da Universidade de Speyer; ${ }^{9}$ e ainda o Código de Processo Administrativo da Federação Russa, em razão do texto ter sido elaborado em função do II Siberian Legal Forum devoted to the development of administrative legal proceedings in Russia. ${ }^{10}$

Faz-se igualmente necessário assinalar o alcance e o contexto de algumas expressões utilizadas no presente estudo: contencioso administrativo relaciona-se às reclamações ou impugnações de um interessado contra comportamentos de uma autoridade administrativa; jurisdição administrativa serve para designar a prestação estatal para solução (coertiva e definitiva) de um contencioso administrativo; justiça administrativa se refere aos órgãos do Estado responsáveis por essa atuação jurisdicional;11 processo administrativo judicial descreve o processo sobre causas de direito administrativo que corre perante órgãos judiciais; processo administrativo extrajudicial refere-se ao processo sobre causas de direito administrativo perante autoridades administrativas; procedimento administrativo designa um processo administrativo extrajudicial sem aptidão para gerar jurisdição (pela ausência de independência das autoridades); funções administrativas primárias recobrem atribuições executivas típicas da Administração Pública; e finalmente as "funções administrativas secundárias relacionam-se a atribuições destinadas à solução de contenciosos administrativos, também denominadas funções administrativas jurisdicionais".12

\footnotetext{
8 Ver GRINOVER, Ada Pellegrini; PERLINGEIRO, Ricardo et al. Código Modelo de Processos Administrativos Judicial e Extrajudicial - para Iberoamérica. Revista Eletrônica de Direito Processual, Rio de Janeiro, v. X, p.360-383. 2012.

9 Ver PERLINGEIRO, Ricardo; SOMMERMANN, Karl-Peter. Euro-American Model Code of Administrative Jurisdiction: English, French, German, Italian, Portuguese and Spanish Versions. Niterói: Editora da UFF, 2014.

10 SIBERIAN LEGAL FORUM, 2, 2016, Tyumen. Administrative justice: comparative and Russian contexts. Rússia, 2016.

11 NÚCLEO DE CIÊNCIAS DO PODER JUDICIÁRIO DA UNIVERSIDADE FEDERAL FLUMINENSE (NUPEJ). Programa de Pós-Graduação Justiça Administrativa (PPGJA/UFF), Niterói, 2008.

12 Ver PERLINGEIRO, Ricardo. Uma perspectiva histórica da jurisdição administrativa na América Latina: tradição europeia-continental versus influência norte-americana. Revista de Investigações Constitucionais, Curitiba, v. 2, n. 1, p. 89-136, jan./abr. 2015.
} 


\section{DIREITO À TUTELA JUDICIAL EFETIVA}

O direito à tutela judicial efetiva é ponto de cristalização do Estado de Direito na América Latina, reconhecido pelos arts. 8.1 e 25 da Convenção Americana de Direitos Humanos como um direito a um tribunal competente, independente e imparcial, o qual respeite as garantias do devido processo legal procedimental para determinação dos direitos individuais, inclusive os de caráter administrativo, nos termos seguintes:

Art. 8.1 Toda pessoa tem direito a ser ouvida, com as devidas garantias, dentro de um prazo razoável, por um juiz ou tribunal competente, independente e imparcial, estabelecido anteriormente por lei, na apuração de qualquer acusação penal formulada contra ela, ou para que se determinem seus direitos ou obrigações de natureza civil, trabalhista, fiscal ou de qualquer outra natureza.

Art. 25.1 Toda pessoa tem direito a um recurso simples e rápido ou a qualquer outro recurso efetivo, perante os juízes ou tribunais competentes, que a proteja contra atos que violem seus direitos fundamentais reconhecidos pela constituição, pela lei ou pela presente Convenção, mesmo quando tal violação seja cometida por pessoas que estejam atuando no exercício de suas funções oficiais.

Art. 25.2 Os Estados Partes comprometem-se: (a) a assegurar que a autoridade competente prevista pelo sistema legal do Estado decida sobre os direitos de toda pessoa que interpuser tal recurso; (b) a desenvolver as possibilidades de recurso judicial; (c) a assegurar o cumprimento, pelas autoridades competentes, de toda decisão em que se tenha considerado procedente o recurso.

Em harmonia com o sistema interamericano de direitos humanos, está assentado nas leis e jurisprudência de grande parte dos países latino-americanos que o direito à tutela judicial efetiva nas causas de direito administrativo compreende três dimensões. ${ }^{13}$

\footnotetext{
13 As três dimensões do direito à tutela judicial efetiva na justiça administrativa foram formuladas por Karl-Peter Sommermann e Ricardo Perlingeiro quando da conclusão do projeto de pesquisa Código Modelo Euro-Americano de Jurisdição Administrativa. Em uma perspectiva comparada, também se extrai tais dimensões da cláusula da tutela judicial efetiva tal como consagrado no art. 4.1 do Código de Justiça Administrativa da Federação Russa (Кодекс административного судопроизводства Российской Федерации).
} 


\subsection{Intensidade}

\subsubsection{Controle sobre o conteúdo das decisões administrativas}

A proteção judicial deve ser plena. A revisão da legalidade formal e material deve incluir, quando apropriado, a verificação do respeito aos limites dos poderes discricionários foram respeitados pela autoridade pública.

A propósito do controle do conteúdo fático e jurídico das decisões administrativas, a Corte I.D.H. afirmou que

Este Tribunal aproxima-se da Corte Europeia, em termos gerais, ao entender que existe uma revisão judicial suficiente quando o órgão judicial examina todas as alegações e argumentos submetidos a seu conhecimento sobre a decisão do órgão administrativo, sem declinar sua competência ao resolvê-los ou a determinar os fatos. Ao contrário, esta Corte considera que não há uma revisão judicial se o órgão judicial está impedido de determinar o objeto principal da controvérsia, como, por exemplo, ocorre em casos em que se considera limitado pelas determinações fáticas ou jurídicas realizadas pelo órgão administrativo que tiverem sido decisivas na resolução do caso. ${ }^{14}$ (tradução nossa)

Acerca da revisão judicial do conteúdo das decisões, bem como dos poderes administrativos discricionários, dispõe o Código Modelo Euro-Americano de Jurisdição Administrativa: 15

Art. 3 (Alcance do controle da legalidade da atuação administrativa)

(1) O tribunal controla a legalidade das ações ou omissões da autoridade administrativa. O controle de legalidade engloba tanto vícios de competência, de procedimento e de forma (legalidade formal ou externa), quanto os conteúdos (legalidade material ou interna). O controle de conteúdo se refere ao exame da fundamentação jurídica do ato individual e do regulamento, bem como dos seus pressupostos fáticos e da qualificação jurídica dos fatos. O tribunal verificará, ainda, se a autoridade administrativa incorreu em desvio de poder.

(2) Cabe ao tribunal, inclusive, examinar a correta aplicação e interpretação de conceitos jurídicos indeterminados por parte da autoridade administrativa.

\footnotetext{
14 CORTE INTERAMERICANA DE DIREITOS HUMANOS. Caso Barbani Duarte y otros vs. Uruguay, São José, 13 de outubro de 2011 , § 204.

15 PERLINGEIRO, Ricardo; SOMMERMANN, Karl-Peter. Euro-American Model Code of Administrative Jurisdiction: English, French, German, Italian, Portuguese and Spanish Versions. Niterói: Editora da UFF, 2014. p. 7-8. Também ver art. 25 do Código Modelo de Processos (Judicial e Extrajudicial) para lbero-América (GRINOVER, Ada Pellegrini; PERLINGEIRO, Ricardo et al. Código Modelo de Processos Administrativos - Judicial e Extrajudicial - para Iberoamérica. Revista Eletrônica de Direito Processual, Rio de Janeiro, v. X, p.360-383. 2012).
} 
Art. 4 (Controle dos poderes discricionários)

(1) Quando a autoridade administrativa tiver exercido poderes discricionários, o tribunal examinará especialmente.

a) se a ação ou omissão administrativa excedeu os limites do poder discricionários;

b) se atuou conforme a finalidade estabelecida na norma que autoriza o poder em questão;

c) se tornou vulneráveis direitos fundamentais ou princípios, como o da igualdade, proporcionalidade, proibição da arbitrariedade, boa fé e proteção da confiança legítima.

(2) Também se controlará a falta de exercício de um poder discricionário.

Art. 5 (Controle de planificação)

[...] o tribunal deve controlar se o ato ou o regulamento se ajusta às leis e, sobretudo, se está motivado. O tribunal também verifica se a autoridade administrativa não incorreu em vícios de ponderação quanto aos bens jurídicos, direitos e interesses que estão em jogo. São vícios de ponderação a falta de exercício ou deficiência administrativa, a não inclusão de bens e interesses relevantes, a atribuição de uma importância inadequada a determinados bens ou interesses (avaliação deficiente de bens e interesses) e a falta de proporcionalidade na ponderação global.

Nessa direção, a Sala Constitucional da Corte Suprema de Justiça da Costa Rica decidiu que:

A função administrativa, de acordo com o parâmetro constitucional (artigos 33 e 409 da Constituição Política), deve ser objeto de um controle de legalidade plenário e universal, sem brechas ou redutos isentos, sobretudo, se são criados e postos em funcionamento para servir ou atender as necessidades dos cidadãos ou administrados - organizações de prestação de serviço. ${ }^{16}$ (grifo do autor e tradução nossa)

Da mesma forma, o Supremo Tribunal Federal brasileiro entende que "não viola o princípio da separação dos poderes o controle judicial de ato administrativo eivado de ilegalidade ou abusividade, o qual envolva a verificação da ocorrência dos

16 COSTA RICA. Corte Suprema de Justicia de San José de Costa Rica. Exp: 04-011636-0007-CO, Res. 036692006, São José, 15 de março de 2006. Ver JINESTA, Ernesto. Principio general de la justiciabidad plenaria y universal de la conducta administrativa. In: BREWER-CARÍAS, Alan et al. (Coord.). La protección de los derechos frente al poder de la administración. Bogotá: Editoriales Temis, tirant lo Blanch y jurídica venezolana, 2014. p. 607-634. A propósito, de acordo com o art. 15 da Ley General de la Administración Pública de Costa Rica (Lei n 6.227, de 28 de abril de 1978), o juiz "exercerá controle de legalidade sobre os aspectos reguladores do ato discricionário e sobre a observância de seus limites". Sobre um controle do conteúdo das decisões administrativas, ver o art. 51 da Ley Federal de Procedimiento Contencioso Administrativo do México, de 4 de outubro de 2005. 
pressupostos de fato e de direito, podendo os tribunais judiciais enfrentarem, inclusive, as questões atinentes à proporcionalidade e à razoabilidade"17 e que "tais tribunais não apenas examinam a proporcionalidade que marca a relação entre meios e fins da decisão administrativa, mas também aquela que se manifesta na relação entre a decisão administrativa e os seus motivos (declarados na motivação da decisão)"18.

Portanto, do ponto de vista dos direitos fundamentais e do princípio da proporcionalidade, a margem de atuação das autoridades (poder discricionário e margem de apreciação) 19 não escapa do controle judicial 20 e, com tal perspectiva, na realidade, a afirmação de que "o juiz não deve interferir na margem de decisão das autoridades"21 deve aplicar-se a situações bem específicas, como as de controle sobre decisões administrativas com conteúdo técnico estranho ao direito, em que o juiz não tem habilitação ou não tem maior habilitação (em relação às autoridades) para controlar o conteúdo (de discricionariedade e de apreciação) daquelas decisões. ${ }^{22}$

\subsubsection{Controle jurisdicional de atos de governo}

Em princípio, atos de governo também se sujeitam a um controle jurisdicional, porém tal questão é ainda controvertida.

Otto Mayer, em sua obra nos fins do século XIX, jamais aceitou a categoria de atos governativos (acte du gouvernement). Segundo ele, a atuação estatal pode ser legislativa, judiciária ou administrativa, nunca governativa, que serviria somente para justificar uma imunidade. 23

17 BRASIL. Supremo Tribunal Federal. Agravo de Instrumento 800.892 Agr/BA. Brasília, 12 de março de 2013. 18 BRASIL. Supremo Tribunal Federal. Recurso em Mandado de Segurança 24.699/DF. Brasília, 30 de novembro de 2004

19 Sobre a diferença entre poderes discricionários, margem de apreciação e conceitos jurídicos indeterminados, ver MAURER, Hartmut. Derecho administrativo alemán. Mexico: UNAM, 2012. p. 21-52.

20 NOBRE JÚNIOR, Edilson Pereira. Direito administrativo contemporâneo. Salvador: Jus Podium, 2016. p. 21. $21 \mathrm{O}$ art. 6 (a) da Ley de la Jurisdiccion Contencioso Administrativa do Equador (Lei $\mathrm{n}^{\circ}$ 35, de 18 de março de 1968) exclui o poder administrativo discricionário da apreciação jurisdicional.

22 Sobre a jurisprudência do Tribunal Federal Administrativo alemão, ver BLANKE, Hermann-Josef. La función del procedimiento administrativo para el cumplimiento del mandato de ejecución, protección y concretización del derecho administrativo. Margenes de discrecionalidad y de apreciación. In: ABERASTURY, Pedro; BLANKE, Hermann-Josef (Ed.). Tendencias actuales del procedimiento administrativo en Latinoamérica y Europa. Buenos Aires: Universidad Buenos Aires, 2012. p. 41. Fábio de Souza Silva adota o critério da confiabilidade da decisão administrativa para medir o grau de interferência judicial na margem de atuação das autoridades administrativas (ver SILVA, Fábio de Souza. Discricionariedade técnica e direito à saúde: confiança como limite para o controle judicial. Niterói, 2014. Tese (Doutorado) - Programa de Pós-graduação em Sociologia e Direito, Universidade Federal Fluminense). Sobre a deferência judicial em favor da Administração, do ponto de vista de discricionariedade técnica, ver JORDÃO, Eduardo. Controle judicial de uma Administração Pública complexa: a experiência estrangeira na adaptação da intensidade do controle. São Paulo: Malheiros, 2016.

23 MAYER, Otto. Derecho administrativo alemán. Buenos Aires: Depalma, 1982. p. 3-5. Sobre as controvérsias acerca do conflito entre atribuições governativas (acte du gouvernement) e as atividades administrativas contenciosas à época, ver FERNÁNDEZ TORRES, Juan Ramon. La pugna entre la Administración y los tribunales 


\section{Segundo Ernesto Jinesta,}

A regra deve ser a de que os atos que emanem dos órgãos do governo, mesmo os de máxima hierarquia e relevância, e que se encontrem submetidos a um regime legal devem ser controlados pela justiça administrativa, uma vez que compete a ela exercer o controle de legalidade, não se admitindo, em nenhum caso, uma zona de imunidade jurisdicional.24 (tradução nossa)

No entanto, diversas leis latino-americanas encontram-se em sentido oposto: art. 6 (c) da Lei da Jurisdição Contencioso-Administrativa do Equador reconhece a categoria de atos políticos do governo e os exclui do controle judicial;25 art. 3 II (a) da Lei de Procedimento Administrativo da Bolívia dispõe que os atos de governo referentes às faculdades de livre nomeação e remoção de autoridades não se sujeitam às regras daquela Lei;26 art. 4 (b) da Lei da Jurisdição do Contencioso Administrativo de Honduras exclui da apreciação jurisdicional "os atos de relação entre os Poderes do Estado ou ligados a relações internacionais, defesa do território nacional e comando e organização militar";27 art. 4 (a) da Lei da Jurisdição Contencioso-Administrativa de El Salvador;28 o art. 21.1 e 21.2 da Lei do Contencioso-Administrativo da Guatemala;29 art. 17.1 da Lei de Regulação da Jurisdição do Contencioso Administrativo da Nicarágua. ${ }^{30}$

\subsection{Pretensões admissíveis}

O direito processual deve garantir que os indivíduos sejam capazes de agir em juízo não só contra as decisões administrativas adversas ou outras medidas com efeito prejudicial a eles, mas também quando a autoridade administrativa não atender a um requerimento ou deixar de fornecer um benefício que o indivíduo considere seu direito. Portanto, o tribunal deve estar investido em poderes para se pronunciar sobre

ordinarios como rasgo sobresaliente del primer constitucionalismo español. In: FERNÁNDEZ TORRES, Juan Ramon. Historia legal de la jurisdicción contencioso-administrativa:1845-1998. Madrid: lustel, 2007.

24 JINESTA, Ernesto. Principio general de la justiciabidad plenaria y universal de la conducta administrativa. In: BREWER-CARÍAS, Alan et al. (Coord.). La protección de los derechos frente al poder de la administración. Libro en homenaje al profesor Eduardo García de Enterría. Bogotá: Editoriales Temis, tirant lo Blanch y jurídica venezolana, 2014. p. 607-634.

25 Lei de Jurisdição Contencioso Administrativo do Equador (Lei n 35, de 18 de março de 1968).

26 Lei de Procedimento Administrativo da Bolivia (Lei n²341, de 23 abril de 2002).

27 Lei da Jurisdição do Contencioso Administrativo de Honduras (Decreto n 189, de 31 de dezembro de 1987).

28 Lei da Jurisdição Contencioso-Administrativa de El Salvador (Decreto n 81, de 14 de novembro de 1978).

29 Lei do Contencioso-Administrativo da Guatemala (Decreto n 119, de 17 de dezembro de 1996).

30 Lei de Regulação da Jurisdição do Contencioso Administrativo da Nicarágua (Lei n 350, de 18 de maio de 2000). 
os deveres correspondentes da autoridade administrativa, e um processo de execução adequado deve estar disponível a fim de tornar tais obrigações efetivas. 31

Sobre a necessidade de o legislador processual consagrar medidas judiciais condenatórias de fazer e de não fazer, a Corte Interamericana de Direitos Humanos afirma que:

Por outro lado, como assinalou anteriormente o Tribunal, ao avaliar a efetividade dos recursos interpostos no âmbito da jurisdição contencioso-administrativa nacional, a Corte deve observar se as decisões tomadas contribuíram efetivamente para pôr fim a uma situação violadora de direitos, para assegurar a não recorrência dos atos danosos e para garantir o livre e pleno exercício dos direitos protegidos pela Convenção. ${ }^{32}$ (tradução nossa e grifo nosso)

Também, segundo a Corte I.D.H., "para que o recurso de nulidade fosse efetivo, teria que implicar tanto a anulação do ato, como a consequente determinação ou, conforme o caso, o reconhecimento dos direitos estabelecidos". 33 (tradução nossa e grifo nosso)

No que concerne às medidas executórias, sistematiza o Código Modelo Euro-Americano de Jurisdição Administrativa: 34

\section{Art. 58 (Medidas)}

A fim de obter a completa execução da sentença ou decisão, o tribunal poderá, a qualquer momento, mediante requerimento da parte, adotar as medidas executivas pertinentes, fixando, quando necessário, um prazo. Pode especialmente:

a) estabelecer uma multa coercitiva;35

\footnotetext{
31 Sobre a necessidade de assegurar meios executivos de sentenças contra as autoridades, ver CORTE INTERAMERICANA DE DIREITOS HUMANOS. Caso Maldonado Ordoñez vs. Guatemala, São José, 3 de maio de $2016, \S 109$.

32 CORTE INTERAMERICANA DE DIREITOS HUMANOS. Caso Barbani Duarte y otros vs. Uruguay, São José, 13 de outubro de 2011, § 201. Na mesma linha: arts. 4 e 5 da Lei que regula o Proceso Contencioso Administrativo do Peru (Lei no 27.584, de 22 de novembro de 2001); art. 9 da Ley Orgánica de la Jurisdicción Contencioso Administrativa da Venezuela (Lei no 39.447, de 16 de junho de 2010); art. 14 da Ley de Regulación de la Jurisdicción de lo Contencioso Administrativo da Nicarágua (Lei n³50, de 18 maio de 2000).

33 CORTE INTERAMERICANA DE DIREITOS HUMANOS. Caso Barbani Duarte y otros vs. Uruguay, São José, 13 de outubro de 2011 , § 211.

34 PERLINGEIRO, Ricardo; SOMMERMANN, Karl-Peter. Euro-American Model Code of Administrative Jurisdiction: English, French, German, Italian, Portuguese and Spanish Versions. Niterói: Editora da UFF, 2014. p. 23-24.

35 Sobre as astreintes, ver arts. 88.2 e 122.3 do Código de Justiça Administrativa da Federação Russa.
} 
b) penhorar bens da autoridade administrativa que não sejam indispensáveis ao cumprimento de tarefas públicas ou cuja alienação não comprometa um interesse público;36 c) ordenar a execução subsidiária a cargo da autoridade administrativa condenada.

Com efeito, a expropriação judicial do patrimônio público, tal como no Código Modelo Euro-Americano vem sendo reconhecido na América Latina com a mesma ressalva de que não deve resultar da execução forçada comprometimento do interesse público. ${ }^{37}$

Nesse ponto, entretanto, a legislação nacional latino-americana não tem sido capaz de estabelecer uma distinção entre interesse público e interesse das autoridades administrativas, tampouco de identificar a sutil diferença entre os efeitos do reconhecimento do interesse público em uma decisão judicial cautelar (provisória) e os efeitos do seu reconhecimento em uma execução de sentença (definitiva), como explica-se na parte final do tópico 2.3 deste texto.

\subsection{Medidas cautelares}

A terceira dimensão da proteção jurisdicional efetiva diz respeito à atualidade da proteção. Proteção judicial tardia é pouco útil. Portanto, o direito processual deve fornecer um sistema de medidas provisórias que possa ser concedido de forma célere e fácil em caso de urgência, abrangendo tanto requerimentos para prevenir o demandante de atos de interferência da Administração, quanto requerimentos para solicitar um benefício ou uma declaração jurídica que sejam necessárias e urgentes. O tribunal deve ser capaz de ordenar que a autoridade administrativa atue ou se abstenha. Se a interferência administrativa a direitos individuais puder levar a consequências irreparáveis, uma medida preventiva também deve ser admitida.

O Código Modelo Euro-Americano de Jurisdição Administrativa está assim disposto: 38

\footnotetext{
36 Ver art. 63 do Código Modelo de Processos (Judicial e Extrajudicial) para Ibero-América (GRINOVER, Ada Pellegrini; PERLINGEIRO, Ricardo et al. Código Modelo de Processos Administrativos - Judicial e Extrajudicial - para Iberoamérica. Revista Eletrônica de Direito Processual, Rio de Janeiro, v. X, p. 360-383. 2012).

37 Ver art. 170 do Código Processual Contencioso-Administrativo da Costa Rica (Lei n 8.508, de 28 de abril de 2006). Sobre o interesse público (serviço essencial à comunidade) como causa de suspensão da execução de uma sentença, ver art. 41 (a) da Ley de la Jurisdicción Contencioso-Administrativa de El Salvador (Decreto n 81, de 14 de novembro de 1978). Ver também art. 110.2 da Ley Orgánica de la Jurisdicción Contencioso Administrativa da Venezuela (Lei $n^{\circ} 39.447$, de 16 de junho de 2010).

38 PERLINGEIRO, Ricardo; SOMMERMANN, Karl-Peter. Euro-American Model Code of Administrative Jurisdiction: English, French, German, Italian, Portuguese and Spanish Versions. Niterói: Editora da UFF, 2014. p. 19. Ver também os arts. 58-60 do Código Modelo de Processos [Judicial e Extrajudicial] para Ibero-América (GRINOVER, Ada Pellegrini; PERLINGEIRO, Ricardo et al. Código Modelo de Processos Administrativos - Judicial e Extrajudicial - para Iberoamérica. Revista Eletrônica de Direito Processual, Rio de Janeiro, v. X, p. 360-383. 2012).
} 
Art. 45 (tutela de urgência)

(1) O tribunal pode conceder uma tutela de urgência. O tribunal deve adotar todas as medidas provisorias de natureza conservatória ou satisfativa e qualquer outra necessária para garantir a efetividade da tutela judicial.

(2) As medidas cautelares se concedem de modo preferencial e sumário, quando haja uma dúvida séria quanto à legalidade da atuação (fumus boni iuris), e a tutela seja urgente (periculum in mora), ponderando os interesses públicos e privados.

A técnica das medidas cautelares atípicas,39 ou seja, a ausência de um procedimento específico pré-determinado a cada espécie de pretensão cautelar, propiciando maior poder discricionário aos juízes, vem sendo adotada em alguns países como Argentina 40 , Brasil41, Colômbia42, México43, Guatemala44 e Venezuela45. A propósito, nessa seara, as regras legais que interferem no poder geral de cautela do juiz, seja para restringir seja para impor a concessão da medida cautelar, devem ser vistas teleologicamente pelo aplicador do direito (juiz e autoridade) como mero indicativo porque, a todo momento, as medidas cautelares sujeitam-se à ponderação entre princípios processuais, tais como o do acesso à justiça e o do direito de defesa. ${ }^{46} \mathrm{~A}$ necessidade como requisito da medida cautelar implica não somente periculum in mora, mas também uma proporcionalidade entre o pedido e a natureza conservativa ou antecipativa da pretensão principal. 47

39 Ver CHITI, Mario Pilade. La tutela cautelare. In: CASSESE, Sabino (Ed.). Corso di dirittto amministrativo. n. 7. 2. ed. Milano: Giuffrè, 2013. p. 170-174.

40 Art. 232 do Código Procesal Civil y Comercial de La Nacion Argentina (Lei n 17.454, de 18 de agosto de 1981).

41 Arts. 300-310 do Código de Processo Civil brasileiro (Lei n 13.105, de 16 março de 2015).

42 Art. 230 do Código de Procedimiento Administrativo y de lo Contencioso Administrativo da Colômbia (Lei n० 1437, de 18 de janeiro de 2011).

43 Art. 24 da Ley Federal de Procedimiento Contencioso Administrativo do México, de $1^{\circ}$ de dezembro de 2005.

44 Art. 18 da Ley de lo Contencioso Administrativo da Guatemala (Decreto n 119, de 17 de dezembro 1996).

45 Arts. 69 e 103-106 da Ley Orgánica de la Jurisdicción Contencioso Administrativa da Venezuela (Lei nº 39.447, de 16 de junho de 2010).

46 Sobre a inconstitucionalidade de leis proibindo medidas judiciais cautelares contra autoridades administrativas, ver BEDAQUE, José Roberto dos Santos. Tutela cautelar e tutela antecipada: tutelas sumárias e de urgência. São Paulo: Malheiros, 1998. p. 84.

47 A despeito de o art. 85.2 do Código de Justiça Administrativa da Federação Russa descrever medidas meramente conservativas ("O tribunal pode suspender os efeitos da decisão impugnada no todo ou em parte, proibir a realização de determinados atos, adotar medidas liminares contra decisões do procedimento administrativo nos casos previstos no $\mathrm{n}^{\circ} 1$ do presente artigo, salvo nas hipóteses em que o presente código assim proíbe quando de categorias previamente determinadas de assuntos administrativos"), e de o art. 85.4 indicar a necessidade de correlação entre o pedido principal e a medida cautelar ("As medidas liminares proferidas contra decisões dos procedimentos administrativos devem ser pertinentes e proporcionais às demandas ajuizadas"), o referido art. 85.2 deve ser interpretado como uma porta para as medidas cautelares também antecipatórias (regulatórias do direito postulado). 
Uma peculiaridade das medidas cautelares na jurisdição administrativa é que não basta a demonstração do periculum in mora e do fumus boni iuris. Para que a pretensão cautelar prospere, é fundamental que haja uma ponderação entre os interesses em colisão, ainda que tais interesses sejam reflexos (referentes a serviços essenciais afetados indiretamente pela decisão cautelar). Dessa ponderação, à luz da proporcionalidade stricto sensu, deve resultar um interesse público preponderante em favor do demandante, isto é, deve-se demonstrar que o resultado da negação da medida cautelar seria mais prejudicial para o interesse público do que a sua concessão, tal como consta literalmente do art. 231.3 do Código de Procedimento Administrativo e do Contencioso Administrativo da Colômbia. 48

Caso, por exemplo, uma medida cautelar que condene autoridades administrativas a entregarem produtos farmacêuticos de alto custo cause sério comprometimento ao orçamento de outros serviços públicos essenciais, talvez fosse mais indicado sacrificar, momentaneamente, o direito fundamental à saúde do demandante e o seu direito à tutela judicial, em favor dos direitos fundamentais de uma coletividade em continuar se beneficiando de outros serviços igualmente essenciais.

Entretanto, não bastaria a alegação de ofensa à saúde pública, à educação ou a outro serviço essencial à sociedade para que a medida cautelar fosse negada. Seria necessário que, no caso concreto, houvesse aferição de qual interesse público mereceria prevalecer: o interesse público na concessão da cautelar ou o interesse público em resguardar outros valores fundamentais a cargo das autoridades?

Portanto, novamente afirma-se que se deve interpretar com ressalvas as leis que proíbem genericamente medidas cautelares 49 e também aquelas leis restritivas que tenham fundamento no interesse público (ou outra denominação que se confira, como ordem social, saúde pública etc.) ${ }^{50}$. Finalmente, merece registro que, se o interesse público predominante for contrário à pretensão do demandante, a improcedência da medida cautelar não implica automaticamente improcedência do pedido principal, isso porque, caso persista manifestando-se o tal interesse público quando da execução

48 Art. 231.3 do Código de Procedimiento Administrativo y de lo Contencioso Administrativo da Colômbia (Lei n 1437, de 18 de janeiro de 2011), impõe seguinte requisito para medidas cautelares, dentre outros: "que o demandante tenha apresentado os documentos, informações, argumentos e justificativas que permitam concluir, mediante um juízo de ponderação de interesses, que resultaria em maior prejuízo para o interesse público negar do que conceder a medida cautelar". Ainda sobre a ponderação entre o interesse público e o privado nas medidas cautelares, ver o art. 104 da Lei Orgânica da Jurisdição Contencioso-Administrativa da Venezuela (Lei $\mathrm{n}^{\circ}$ 39.447, de 16 de junho de 2010).

49 Ver o art. 7 da Lei sobre o Mandado de Segurança individual e coletivo (Lei $n^{\circ} 12.016$, de 7 de agosto de 2009).

50 No direito brasileiro, consta do art 15 da Lei sobre o Mandado de individual e coletivo que o interesse individual cede a uma grave lesão à ordem, à saúde, à segurança e à economia públicas. No mesmo sentido, o art. 22 do Código de Processo Contencioso-Administrativo da Costa Rica (Lei n 8.508, de 28 de abril de 2006) que indica a necessidade da medida cautelar ser compatível com as previsões orçamentárias das autoridades administrativas. 
da sentença, o demandante deve ser compensado economicamente pelo sacrifício pessoal em favor da coletividade51. Essa compensação financeira, em sede de medida cautelar provisória não seria justificável.

\subsection{Judicialização exacerbada}

No entanto, a despeito de tamanha evolução do direito a uma tutela judicial efetiva, a realidade dos tribunais latino-americanos demonstra um panorama de adversidades: uma judicialização exacerbada, com milhares de processos em andamento, ora por iniciativa de particulares, ora por iniciativa de autoridades contra particulares, como evidente consequência de uma crescente perda de credibilidade generalizada dos cidadãos na Administração Pública, sem que haja uma resposta jurisdicional e proporcional a cargo dos tribunais.

No Brasil, o volume de processos continua aumentando, apesar da melhoria de produtividade dos juízes, que atingiu uma média de 1.564 sentenças por juiz em 2013.52 No último relatório de 2014, elaborado pelo Conselho Nacional de Justiça - CNJ, os tribunais atingiram 100 milhões de causas em tramitação, quando o estoque é de 70,8 milhões de processos, acrescido de 28,9 milhões de casos novos. 53 Conforme pesquisa do CNJ a respeito dos 100 maiores litigantes no país, a Administração Pública federal lidera, com um total de 38,5\%, seguida da Administração Pública estadual, com $7,8 \%$, e da municipal, com $5,2 \%$, o que perfaz um total de $51,5 \%$ entre todos os entes da Administração Pública.

Isso significa dizer que a Administração Pública alcança um número de demandas maior do que o dos demais 80 maiores litigantes do país, incluídos todo o setor bancário e o de telefonia. 54 Na referida listagem dos 100 Maiores Litigantes do País, constatou-se a liderança do Instituto Nacional do Seguro Social - INSS, com participação de $22,33 \%$ no total dos processos do acervo. 55

\footnotetext{
51 Sobre a compensação financeira, pelo sacrifício individual de sentença não cumprida, ver COLOMBIA. Corte Constitucional de la República de Colombia. Sentença T-554/92. Santa Fé de Bogotá, 9 de outubro de 1992. Também ver o acima citado art. 110.2 da Lei Orgânica da Jurisdição Contencioso-Administrativa da Venezuela.

52 CONSELHO NACIONAL DE JUSTIÇA. Justiça em números: ano base 2013. Brasília: CNJ, 2014. p. 39.

53 Ver CARDOSO, Maurício. Brasil atinge a marca de 100 milhões de processos em tramitação na Justiça. Consultor Jurídico, São Paulo, set. 2015. Disponível em: <http://www.conjur.com.br/2015-set-15/brasil-atinge-marca-100-milhoes-processos-tramitacao>. Acesso em: 31 jan 2017. Ver também CONSELHO NACIONAL DE JUSTIÇA. Justiça em números: ano base 2014. Brasília: CNJ, 2015. p. 25-58.

54 Ver CONSELHO NACIONAL DE JUSTIÇA. 100 maiores litigantes. Brasília: Departamento de Pesquisas Judiciárias, 2011.

55 Ver CONSELHO NACIONAL DE JUSTIÇA. 100 maiores litigantes. Brasília: Departamento de Pesquisas Judiciárias, 2011
} 
Nos tribunais costa-riquenhos, desde o advento do Código de Processo Contencioso-Administrativo da Costa Rica,56 ocorreu um imenso incremento do número de causas do contencioso administrativo: de 1.195 causas em tramitação em 2008, chegou-se ao número de 14.182 em 2015.57 No México, junto aos tribunais colegiados de circuito, tribunais unitários de circuito e juizados de distrito, em matéria de direito administrativo, ingressaram 283.843 novas ações judiciais em 2013, e 302.500 em 2014.58 Na Argentina, em 2006, ingressaram 60.307 novas ações, encontrando-se pendentes 118.018 causas, e, em 2014, foram registradas 44.220 novas ações, com 220.174 em tramitação. ${ }^{59}$ No Paraguai, em 2012, o Tribunal de Contas recebeu 585 causas, e, em 2015, surgiram 853 novas demandas de contencioso administrativo. 60

Em El Salvador, em 2015, na Corte Suprema de Justiça, 2.291 casos de contencioso administrativo, enquanto, em 2011, encontravam-se 1.692 processos pendentes. 61 No Panamá, em 1990, na Suprema Corte Judicial, ingressaram 383 demandas de contencioso administrativo, e, em 2010, a distribuição de novas causas alcançou o número de 963.62 Em 2006, na Nicarágua, constavam como interpostas 14 demandas perante a Sala do Contencioso Administrativo da Corte Suprema de Justiça; em 2014; esse número chegou a 213 e, em 2015, havia 161 novas causas. 63

Em um cenário mais favorável, com estatísticas que indicam estabilidade, estão Uruguai, Honduras e Bolívia.

No Uruguai, a estatística do Tribunal do Contencioso Administrativo aponta uma constância de número de processos desde 1991, quando havia 985 causas em curso, e, no ano 2015, 791 processos. 64 Em Honduras, em 2006, foram 221 novos casos junto às Cortes de Apelações, 840 nos Juizados de Letras Contencioso Administrativo, e 27 nos Juizados de Letras Fiscal Administrativo, e em 2015 foi registrado o ingresso

\footnotetext{
56 Código de Processo Contencioso-Administrativo da Costa Rica (Decreto Legislativo n 8.548 , de 28 de abril de 2006, que entrou em vigor em $1^{\circ}$ de janeiro de 2008).

57 Ver PODER JUDICIAL DA REPÚBLICA DE COSTA RICA 2016.

58 DIRECCIÓN GENERAL DE ESTADÍSTICAS JUDICIAL DE LOS ESTADOS UNIDOS MEXICANOS. Estadística Nacional - Anual 2014. México, 2014.

59 JUNTA FEDERAL DE CORTES Y SUPERIORES TRIBUNALES DE JUSTICIA DE LAS PROVINCIAS ARGENTINAS Y CIUDAD AUTÓNOMA DE BUENOS AIRES. Indicadores 2006, Buenos Aires, 2006. JUNTA FEDERAL DE CORTESY SUPERIORES TRIBUNALES DE JUSTICIA DE LAS PROVINCIAS ARGENTINAS Y CIUDAD AUTÓNOMA DE BUENOS AIRES. Indicadores 2014, Buenos Aires, 2014.

60 Ver CORTE SUPREMA DE JUSTICIA DEL PARAGUAY. Dirección de Estadísticas Judicial, Asunción, 2016.

61 CORTE SUPREMA DE JUSTICIA DE LA REPÚBLICA DE EL SALVADOR. Estadística Institucionales, San Salvador, 2016.

62 ÓRGANO JUDICIAL DE LA REPÚBLICA DE PANAMÁ. Estadísticas Judiciales, Ancón, 2011.

63 CORTE SUPREMA DE JUSTICIA DE LA REPÚBLICA DE NICARAGUA. Sala de lo Contencioso Administrativo. Estadistica 2015, Managua, 2015.

64 TRIBUNAL DE LO CONTENCIOSO ADMINISTRATIVO DE LA REPUBLICA DE URUGUAY. Estadísticas, [S.I.], 2016.
} 
de 380, 449 e 37 causas junto aos citados tribunais, respectivamente.65 Na Bolívia, em 2012, tramitavam 4.619 ações perante o Tribunal Supremo de Justiça, 3.972 nos Tribunais Departamentais de Justiça, 176 no Tribunal Agroambiental, e 9.004 nos Juizados Administrativos Coercitivos Fiscais e Tributários. Em 2014, eram 1.151 causas no Tribunal Supremo de Justiça, 5.446 nos Tribunais Departamentais de Justiça, 434 no Tribunal Agroambiental, e 9.929 causas nos Juizados Administrativo Coercitivo Fiscal e Tributário.66

\section{DESAFIOS REFERENTES AO SISTEMA JUDICIÁRIO}

\subsection{Razões históricas da crise de identidade do sistema judicial}

Na verdade, a judicialização exacerbada relaciona-se à forma de organização da jurisdição administrativa em uma América Latina fiel à tradição do direito europeu-continental, decorrente de suas raízes históricas na Península Ibérica, em choque com a influência do constitucionalismo norte-americano, que fora exemplar para os processos de independência que varreram as colônias ibéricas do território americano a partir do início do séc. XIX.67

Em geral, nos países vinculados ao common law (especialmente nos EUA, Reino Unido e Austrália) as courts são generalistas (sem especialização) e, com o seu closed judicial review, tendem não adentrar nos fundamentos de fato das decisões administrativas. 68 Tal estrutura é compensada com a existência de agências administrativas ( $a d m i-$ nistrative tribunals, administrative judges), dotadas de independência, quase-judiciais, e que se situam dentro da estrutura de uma Administração Pública com aptidão para propiciar aos cidadãos um devido processo legal.69

Na maioria dos sistemas jurídicos da Europa continental (com origem no civil law), ao contrário, os tribunais são especializados em direito administrativo e tendem a amplos poderes de revisão do conteúdo fático das decisões administrativas, o que,

65 CENTRO ELECTRÓNICO DE DOCUMENTACIÓN E INFORMACIÓN JUDICIAL DE HONDURAS. Unidad de Estadistica. Honduras, 2015.

66 CONSEJO DE MAGISTRATURA DE BOLIVIA. Anuário Estadístico Judicial 2012. Bolivia: Editorial Judicial, 2012; e CONSEJO DE MAGISTRATURA DE BOLIVIA. Anuário Estadístico Judicial 2014. Bolivia: Editorial Judicial, 2014.

67 Ver PERLINGEIRO, Ricardo. Uma perspectiva histórica da jurisdição administrativa na América Latina: tradição europeia-continental versus influência norte-americana. Revista de Investigações Constitucionais, Curitiba, v. 2, n. 1, p. 89-136, jan./abr. 2015.

68 Ver ASIMOW, Michael. Five Models of Administrative Adjudication. American Journal of Comparative Law, Michigan, v. 63, n. 4, p. 3-32, setp./dec. 2015.

69 Ver CANE, Peter. Administrative law. 5 ed. New York: Oxford University Press, 2011. p. 96. Ver também STRAUSS, Peter. An introduction to administrative justice in United States. Durham: Carolina Academic Press, 1989. 
entretanto, compensa uma Administração Pública tradicionalmente sem vocação jurisdicional. 70

Nesse contexto, os sistemas de jurisdição administrativa latino-americanos enfrentam uma crise de identidade, porque leis processuais e suas interpretações tentam conciliar, sem êxito, as características do modelo europeu com as do modelo norte-americano.

Em grande parte dos países da América Latina, adota-se um Judiciário generalista (não especializado em matéria administrativa). Dos 18 países estudados, 13 mantêm o sistema de jurisdição única e, quase sempre, com uma estrutura judiciária dotada de especializações ocasionais: Argentina71, Bolívia72, Brasil73, Costa Rica74, Chile75, El Salvador76, Equador77, Honduras78, Nicarágua79, Panamá80, Paraguai81, Peru82 e Venezuela83. São exemplos de jurisdição dualista, isto é, de uma jurisdição administrativa especializada e autônoma em três níveis (1o e 20 graus, além de uma corte suprema), apenas a

70 Sobre os modelos de jurisdição administrativa na Europa, ver FROMONT, Michel. Droit administratif des États européens. Paris: PUF, 2006. p. 120 et seq. Ver também ZILLER, Jacques. Administrations comparées: les systèmes político-administratifs de l'Éurope des Douze. Paris: Montchrestien, 1993. A Federação Russa adota um sistema judicial monista, como se depreende dos arts. 1.1 e 17 do Código de Justiça Administrativa da Federação Russa.

71 Ver MAIRAL, Héctor A. Control judicial de la Administración Pública. Buenos Aires: Depalma, 1984. p. 124-126.

72 Art. 179 da Constitución Política del Estado Plurinacional de Bolívia de 2008.

73 Constituição Federal da República Federativa do Brasil de 1988.

74 Constitución Política de la República de Costa Rica de 1949.

75 Ver VERGARA BLANCO, Alejandro. Panorama general del derecho administrativo chileno. In: GONZÁLEZ-VARAS IBÁÑNEZ, Santiago (Coord.). El derecho administrativo iberoamericano. Granada: INAP, 2005. p. 159161.

76 Art. 131.3 da Constitución de la República de El Salvador de 1983.

77 Arts. 188.3 e 173 da Constitución Política del Ecuador de 2008.

78 Constitución del Estado de Honduras de 1982.

79 Art. 163 da Constitución Política de la República de Nicaragua de 1987. Ver CORTE SUPREMA DE JUSTICIA DE REPÚBLICA DE NICARAGUA. Sala de lo Contencioso Administrativo. Antecedentes y Creación de la Sala de lo Contencioso Administrativo, 2016.

80 Art. 206 da Constitución Política de la República de Panamá de 1972 (com redação da Emenda Constitucional de 2004).

81 Art. 248 da Constitución Nacional de la República del Paraguay de 1992. Sobre o sistema judicialista paraguaio em que o Judiciário exerce jurisdição sobre o contecioso administrativo, verLuis Enrique. La justicia constitucional y la justicia administrativa. In: In: HERNÁNDEZ-MENDIBLE, Víctor (Coord.). Derecho administrativo iberoamericano. Tomo 2. Caracas: Ediciones Paredes, 2007. p. 1212.

82 HUAPAYA TAPIA, Ramón Alberto. Tratado del processo contencioso administrativo. Lima: Jurista Editores, 2006. p. 335.

83 Ver BREWER-CARÍAS, Allan Randolph. Instituiciones políticas y constitucionales. Tomo VIl: La justicia contencioso administrativo. Caracas: Editorial Juridica Venezolana, 1997. p. 21 et seq. 
Colômbia84, a Guatemala85 e a República Dominicana86. O único caso de tribunal administrativo extrajudicial é o do Uruguai87.

O México é um exemplo à parte, porque a sua Constituição adota o sistema judicial monista, mas também prevê que a lei crie tribunais administrativos, alheios à estrutura judiciária, 88 de cujas decisões caiba somente o recurso de amparo judicial, referente a questões constitucionais. ${ }^{89}$ Dessa forma, os tribunais administrativos mexicanos se assemelham ao Tribunal do Contencioso Administrativo do Uruguai. 90

O devido processo legal perante autoridades administrativas, como condição prévia ao início dos efeitos de uma decisão administrativa restritiva de direitos individuais, a exemplo dos regimes jurídicos associados ao common law, ${ }^{91}$ aparece nas

84 Art. 231 Constitución Politica de Colombia de 1991.

85 Constituições da Guatemala de 1945 (art. 164), de 1956 (arts. 193 e 194), de 1965 (art. 255) e de 1985 (art. 221).

86 Arts. 164 e 165 da Constitución Política de la República Dominicana de 2010.

87 Arts. 307 a 321 da Constitución de la República Oriental del Uruguay de 1967.

88 Arts. 73 XXIX, 94, 116V e 122 Base Quinta da Constitución Política de los Estados Unidos Mexicanos de 1917. Sobre a natureza do Tribunal Federal Fiscal Administrativo, ver MARGÁIN MANAUTOU, Emilio. De lo contencioso administrativo: de anulación o de ilegitimidade. México: Porrúa, 2009. p. 2 et seq.

89 Art. 107 IV e V (b) da Constitución Política de los Estados Unidos Mexicanos de 1917. Sobre o controle judicial da Administração em geral, ver FERNÁNDEZ RUIZ, J. Panorama general del derecho administrativo mexicano. In: GONZÁLEZ-VARAS IBÁÑEZ, Santiago (Coord.). El derecho administrativo iberoamericano. Granada: INAP, 2005. p. 462-463.

90 Sobre a natureza de tribunal autônomo dos tribunais administrativos no México e do Uruguai, ver PERLINGEIRO, Ricardo. Uma perspectiva histórica da jurisdição administrativa na América Latina: tradição europeia-continental versus influência norte-americana. Revista de Investigações Constitucionais, Curitiba, v. 2, n. 1, p. 89-136, jan./abr. 2015.

91 Emendas Constitucionais V e XIV. Sobre a origem do due process of law na Magna Carta, ver MCKECHNIE, William Sharp. Magna Carta: A Commentary on the Great Charter of King John, with an Historical Introduction. Glasgow: Maclehose, 1914. p. 377. Sobre a aplicação do due process of law no direito administrativo dos Estados Unidos, ver ESTADOS UNIDOS. U.S. SUPREME COURT. Case Murray's Lesver v. Hoboken Land \& Improvement Co. 59 U.S. 272, 19 de fevereiro de 1856; ESTADOS UNIDOS. U.S.SUPREME COURT. Case Goldberg v. Kelly, 397 U.S. 254, 23 de março de 1970, e ver também Administrative Procedure Act (5 U.S.C. Subchapter II) de 11 de junho de 1946. 
Constituições do Brasil92, Colômbia93, Equador94, Nicarágua95, República Dominicana96 e Venezuela97, e nas leis da Argentina98, Bolívia99, Peru100 e Uruguai101.

Segundo a Corte Suprema da Argentina,

as garantias constitucionais do devido processo e da defesa em juízo são de observância indispensável em todo tipo de atuação, inclusive em procedimentos administrativos de natureza disciplinar - sejam ou não sumários - de modo que o imputado possa ter a oportunidade de ser ouvido e provar, de algum modo, os fatos que acredita conduzir à sua absolvição.102 (tradução nossa)

Contudo, tal garantia processual (extrajudicial) não está efetivamente implementada, uma vez que a realidade cultural europeia-continental das Administrações Públicas latino-americanas não é condizente com uma perspectiva de autoridades especializadas, independentes ou quase-independentes, típicas do direito administrativo nos países de common law. ${ }^{103} \mathrm{Em}$ geral, as leis latino-americanas de procedimento administrativo preveem somente as causas de impedimento e de suspeição dos funcionários públicos que exercem funções decisórias em processos administrativos (extrajudicial), de modo a garantir a imparcialidade. ${ }^{104}$

92 Art. 5 LIV e LV da Constituição da República Federativa do Brasil de 1988.

93 Art. 29 da Constitución Política de Colombia de 1991.

94 Arts. 23.27 e 76 da Constituição do Equador.

95 Art. 34 da Constituição da Nicarágua.

96 Art. 69 da Constituição da República Dominicana.

97 Art. 49 da Constitución de la República Bolivariana de Venezuela de 1999.

98 Art. 1 (f) da Ley de Procedimiento Administrativo da Argentina (Lei no 19.549, de 3 de abril de 1972).

99 Art. 4 (c) da Ley Procedimiento Administrativo de Bolivia de Procedimiento Administrativo (Lei n 2341, de 23 abril de 2002).

100 Art. IV 1.2 da Ley del Procedimiento Administrativo General do Peru (Lei n²7.444, de 21 de março de 2001).

101 Art. 5 das Normas generales de actuación administrativa y regulación del procedimiento en la Administración Central do Uruguai (Decreto n 500, de 27 de setembro de 1991).

102 ARGENTINA. Corte Suprema de Justicia de la Nacion Argentina. Jueces Nacionales en lo Criminal y Correccional Federal de la Capital Federal s/ avocación. S. 1492.95, Buenos Aires, 02 de julho de 1996, p. 1160.

103 Sobre a Assembleia Constituinte brasileira, em 1987, contrária à criação de agências com funções jurisdicionais, ver GUERRA, Sérgio. Aperfeiçoando a regulação brasileira por agências: quais lições podem ser extraídas do sequiscentenário modelo norte-americano? In: (Coord.). Teoria do Estado regulador. Curitiba: Juruá Editora, 2015. p. 89-92.

104 Art. 6 da Ley Argentina de Procedimiento Administrativo (Lei $\mathrm{n}^{\circ}$ 19.549, de 3 de abril de 1972); arts. 3.3 e 11 do Código colombiano Procedimiento Administrativo y de lo Contencioso Administrativo (Lei $n^{\circ} 1437$, de 18 de janeiro de 2011); arts. 4 e 11 da Ley de los Procedimientos Administrativos do Chile (Lei n 19.880, de 29 de maio de 2003); Arts. 4(f) e 10 da Ley de Procedimiento Administrativo da Bolívia (Lei n 2341, de 23 abril de 2002); art. 2(a) e 3 das Normas generales de actuación administrativa y regulación del procedimiento en la Administración Central do Uruguai (Decreto no 500, de setembro de 1991); art. IV 1.5 e art. 88 da Lei peruana de Procedimento Administrativo Geral (Lei n 27.444, de 21 de março de 2001); art. 10 da Ley Federal de Procedimiento Contencioso Administrativo do México; arts. 18-21 da Lei de Processo Administrativo no âmbito da Administração Pública Federal (Lei n 9.784, de 29 de janeiro de 1999). 
O título do art. 3.11 da Lei do Procedimento Administrativo da República Dominicana se refere expressamente à independência:

11. Princípio da imparcialidade e independência. O pessoal a serviço da Administração Pública deverá abster-se de toda atuação arbitrária ou que ocasione tratamento preferencial por qualquer motivo e atuar em função do serviço objetivo ao interesse geral, proibindo-se a participação do referido pessoal em qualquer assunto em que ele mesmo, familiares ou pessoas próximas tenham qualquer tipo de interese ou em que possa existir conflito de interesses 105 (tradução nossa e grifo nosso)

Entretanto, como se observa, há um erro conceitual acerca de independência; na verdade, o citado artigo de lei se refere apenas à imparcialidade.

Os poucos exemplos latino-americanos de quasi judicial bodies situam-se na área do direito de acesso à informação oficial, mediante respaldo da Lei Modelo Interamericana de Acesso à Informação Pública,106 como no Chile, com o Conselho de Transparência;107 em El Salvador, com o Instituto de Acesso à Informação Pública;108 em Honduras, com o Instituto de Comissários; ${ }^{109}$ e no México, com o Instituto e os Organismos Garantes. ${ }^{110}$

Portanto, a jurisdição administrativa latino-americana tende a concentrar-se em tribunais judiciais que não integram uma estrutura especializada.

\subsection{Os extremos: deferência administrativa e controle judi- cial intenso}

Um Judiciário generalista pode se sentir tentado a agir como as courts americanas, abstendo-se de controlar as questões fáticas das decisões administrativas, e limitando-se a uma revisão de legalidade e (principalmente) formal das decisões impugnadas. ${ }^{111}$ No entanto, diante de uma Administração Pública desprovida de prerrogativas para exercer suas atribuições com independência, uma tal deferência judicial em prol

\footnotetext{
105 Art. 3.11 da Ley del Procedimiento Administrativo da República Dominicana (Lei n 107-13, de 3 de abril de 2013).

106 ORGANIZAÇÃO DOS ESTADOS AMERICANOS. Lei Modelo Interamericana de Acesso à Informação Pública. AG/RES. 2607 (XL-0/10), 2010.

107 Arts. 31-44 da Ley sobre Acceso a la Información Pública (Lei n²0.285, de 20 agosto de 2008).

108 Arts. 51-60 da Ley de Acceso a la Información Pública (Decreto n 534, de 2 de dezembro de 2010).

109 Arts. 8-11 da Ley de Transparencia y Acceso a la Información Pública (Decreto Legislativo n 170, de 30 de dezembro de 2006).

110 Arts. 8. III e IV, 30 e 37-42 da Ley General de Transparencia y Acceso a la Información Pública do México.

111 ESTADOS UNIDOS. U.S. SUPREME COURT. Case Chevron U.S.A., INC, v. Natural Resources Defense Council, Inc. 467 U.S. 837, 25 de junho de 1984. Sobre a deferência, em diversos sistemas jurídicos, ver JORDÃO, Eduardo. Controle judicial de uma Administração Pública complexa: a experiência estrangeira na adaptação da intensidade do controle. São Paulo: Malheiros, 2016.
} 
de autoridades geraria uma sensação de fragilidade do cidadão e de imunidade do Estado.

Em outro extremo, a adoção de um amplo poder de controle sobre as decisões administrativas pelos tribunais judiciais, tal como os tribunais especializados nos países europeus, paradoxalmente, tem levado à inefetividade da proteção judicial. Como o Judiciário latino-americano é generalista, sem especialização, é uma realidade juízes com poderes intensos tratarem os conflitos de direito púbico como se fossem de direito privado fossem, e sem olhos para o interesse público, isto é, tendendo a aplicar princípios de direito privado e de direito processual civil a causas de direito administrativo, ${ }^{112}$ fracionando em demandas individuais causas que, com fundamento em interesse geral, são essencialmente coletivas e, assim, propensas à multiplicação. ${ }^{113}$ Isso ocorre especialmente no Brasil, em que, até a presente data, não há uma lei geral de processo administrativo judicial.

É exemplo de decisão judicial, com amplos poderes sobre as autoridades e um viés de direito privado em relações jurídicas tipicamente de direito público, aquela que, em execução forçada de sentenças, implica expropriação do patrimônio público sem considerar os casos de risco de ofensa ao interesse público. ${ }^{114}$ Outro exemplo é

112 O ordenamento jurídico anglo-americano não está assentado na distinção entre o direito público e o direito privado (ver WOLF, Hans J. et al. Direito Administrativo. v. 1. Lisboa: Fundação Calouste Gulbenkian, 2006. p. 267; e CANE, Peter. Administrative law. 5 ed. New York: Oxford University Press, 2011. p. 4). Atualmente, o que Dicey sustentava - "a possibilidade de processar funcionários do governo em tribunais ordinários de acordo com princípios de direito privado é um primado do Estado de Direito" - é amenizado no direito inglês com um fair hearing na fase administrativa, o que, entretanto, na prática, inexiste até o momento na América Latina. CANE, Peter. Administrative law. 5 ed. New York: Oxford University Press, 2011. p. 44.

113 Sobre a inadequação de princípios de direito processual civil aplicáveis a conflitos de direito administrativo, e sua relação com o aumento de demandas repetitivas, ver CLEMENTINO, Marco Bruno M. As demandas repetitivas de direito público e o princípio da procedimentalização da isonomia. In: MORAES, Vânila Cardoso André de (Coord.). As demandas repetitivas e os grandes litigantes. Brasília: Enfam, 2016. p. 23-52. Ver também ALVES, Clara da Mota S. Pimenta. Sistema brasileiro de precedentes: uma promessa não cumprida de redução da litigiosidade? In: MORAES, Vânila Cardoso André de (Coord.). As demandas repetitivas e os grandes litigantes. Brasília: Enfam, 2016. A propósito, a Corte Suprema do Chile recomendou ao Ministério da Justiça que considerasse em projeto de lei a especialização dos tribunais em matéria de contencioso administrativo, e ainda a elaboração de norma processual única e especializada, como alternativas à insegurança jurídica e à litigiosidade excessiva (Corte Suprema), Acta 176, de 24 de outubro de 2014).

114 Ver SOUZA, Giselle. Justiça determina novo arresto nas contas do governo do Rio de Janeiro. Consultor Jurídico, São Paulo, mai. 2016. Disponível em: < http://www.conjur.com.br/2016-mai-09/justica-determina-arresto-contas-governo-rj>. Acesso em: 31 jan 2017; Ver também EL NACIONAL WEB. Fapuv denunció incumplimiento del gobierno al no respoder exigencias universitarias en 48 horas, Caracas, 2016. Na Itália, a execução forçada da Administração é cabível nas causas de direito privado e perante o juiz ordinário (civil). No âmbito da jurisdição administrativa, a execução de decisões judiciais (inclusive se disser respeito a pagamento de valores) dá-se mediante o giudizio di ottemperanza. A execução de sentenças contra a Administração proferidas por juízes civis excepcionalmente se dá via giudizio di ottemperanza, quando houver questões de direito público na fase executiva (ver CLARICH, Marcello. L'esecuzione. In: SANDULLI, Aldo (Ed.). Corso de Diritto Amministrativo: Diritto Processuale Amministrativo. n. 7. Milano: Giuffrè, 2013. p. 302-303). 
a decisão judicial que decreta a nulidade de um certame público apenas em favor do demandante, sem considerar os demais candidatos ou interessados. 115

Entre os dois extremos ocasionados pela falta de especialização em direito administrativo do Poder Judiciário e da legislação processual, vale citar os acordos judiciais. Ora os juízes e as leis processuais podem ser refratários a qualquer modalidade de solução consensual de conflitos (arbitragem, mediação, transação) e, valendo-se de uma interpretação estendida de direitos indisponíveis, confundirem interesse público com interesse das autoridades, em contraste com a realidade de diversos setores da Administração que já são capazes de promover tais acordos na esfera administrativa extrajudicial. Ora os juízes e as leis processuais podem sentir-se propensos a admitir acordos, mas nem sempre atentos aos princípios de direito administrativo, tais como o da legalidade e o da isonomia, tornando-se vulneráveis a distorções e desvios de conduta que comprometem a própria noção de tutela judicial efetiva.

\subsection{Credibilidade a partir da especialização dos tribunais}

Em um sistema jurídico em que os tribunais judiciais detêm amplo poder de controle das autoridades, a ausência de especialização da jurisdição administrativa pode levar também à ausência de credibilidade da Administração Pública em relação às sentenças judiciais e, portanto, a uma resistência ainda maior que ela propicie, por sua própria conta, efeito geral (erga omnes) a uma sentença que tenha reconhecido, incidenter tantum, uma questão de interesse geral em um caso individual.

Em geral, autoridades administrativas são recalcitrantes a medidas jurisdicionais que consideram fruto de desconhecimento técnico dos juízes. ${ }^{116}$

A desconfiança da Administração em relação ao Judiciário é também notada pela subsistência de leis processuais que excepcionam o princípio da paridade de armas, como as que atribuem prazos processuais mais benéficos em favor das autoridades e limitam a eficácia das sentenças dos juízes de primeiro grau à confirmação pelos tribunais de apelação. ${ }^{117}$

115 CERS Curso OnLine. Candidato consegue na Justiça anulação dos quesitos de duas questões da prova de concurso para advogado da União, Recife, jan. 2016. Disponível em: < http://blog.cers.com.br/candidato-consegue-na-justica-anulacao-dos-quesitos-de-duas-questoes-da-prova-do-concurso-para-advogado-da-uniao/>. Acesso em: 31 jan 2017.

116 Ver CATANHO, Lucas. Gasto com ações judiciais na Saúde cresce 400\% em 5 anos: Despesa saltou de R\$ 3,7 mi, em 2010, para R\$18,7 mi em 2015, na região de Ribeirão Preto; Estado acusa custo 'desnecessário'. A Cidade On Ribeirão Preto, Ribeirão Preto, maio. 2016. Disponível em: < https://www.acidadeon.com/ribeiraopreto/cotidiano/cidades/NOT,2,2,1169336,Gasto+com+acoes+judiciais+na+Saude+cresce+400+em+5+anos. aspx>. Acesso em: 31 jan. 2017; e G1Rio. Governo do RJ descumpre ordem de pagar salários a aposentados. 0 Globo, Rio de Janeiro, abr. 2016. Disponível em: < http://g1.globo.com/rio-de-janeiro/noticia/2016/04/justica-manda-conferir-se-rj-pagou-aposentados-e-pensionistas.html>. Acesso em: 31 jan. 2017.

117 ROQUE, André Vasconcelos et al. O novo CPC e a desconfiança nos juízes. Jota, São Paulo, jun. 2015. Disponível em: <http://jota.info/artigos/o-novo-cpc-e-a-desconfianca-nos-juizes-15062015>. Acesso em: 31 jan 


\subsection{Individuais as demandas repetitivas?}

O Código de Processo Administrativo da Federação Russa criou um avançado e específico sistema de ações coletivas para a jurisdição administrativa, estabelecendo uma regra de competência processual que considera a natureza e alcance da decisão administrativa impugnada (arts. 17, 19, 20 e 21); ações coletivas de iniciativa do Ministério Público e de entidades públicas e associativas para proteção de interesse difuso, em que os beneficiários possam ser indeterminados (arts. 39 e 40); 118 e ações coletivas, de iniciativa dos próprios interessados, para proteção de interesses individuais homogêneos de um grupo determinado de pessoas (art. 42). Nesse caso, o legislador se preocupou com a necessidade de igualdade de tratamento a todos os membros do grupo (art. 42.1(4)), 119 na medida em que a questão de fundo envolve um comportamento administrativo de alcance geral (art. 42.1(3)).120

Tais preocupações têm movido alguns legisladores latino-americanos para a mesma direção, com procedimentos que buscam a igualdade de tratamento a demandas individuais repetitivas na jurisdição administrativa, como na Costa Rica, com o Processo Unificado, 121 na Nicarágua, com a concentração de competência para decidir demandas individuais fundadas em questões de interesse geral e com o efeito erga omnes de sentenças que reconhecem a nulidade de ato administrativo com efeito geral, 122 e no Brasil, com o Incidente de Demandas Repetitivas. ${ }^{123}$ No mesmo sentido, encontram-se o art. 44 do Código Modelo Euro-Americano de Jurisdição Administrativa124 e o

2017. O Código de Processo Civil brasileiro prevê prerrogativas (privilégios) processuais em favor das autoridades administrativas, tais como o prazo processual diferenciado (art. 183), e a eficácia da sentença (condenatória da autoridade) condicionada à confirmação pelo tribunal de apelação (art. 496).

118 Art. 39. [... ] O Ministério Público é legitimado para ajuizar demandas nos tribunais em defesa dos direitos, liberdades e interesses legítimos dos cidadãos, de um grupo indeterminado de pessoas ou de interesses da Federação Russa, entidades constituintes da Federação Russa, órgãos municipais e em outros casos previstos por lei federal. Art. 40.1 [...] Nos casos previstos pela Constituição, pelo presente Código e por outras leis federais, órgãos governamentais, autoridades administrativas, o Comissário para os Direitos Humanos da Federação Russa e o Comissário para os Direitos Humanos de uma entidade constituinte da Federação Russa podem recorrer aos tribunais em defesa dos direitos, liberdades e interesses jurídicos de um conjunto indeterminado de pessoas e de interesses públicos.

119 Art. 42.1(4) Todos os membros do grupo devem utilizar os mesmos meios de defesa para os seus direitos.

120 Art. 42.1(3) Art. 42.1(3) disponibilidade de uma defesa administrativa comum (administrative co-defendants).

121 Art. 48 do Código Procesal do Contencioso-Administrativo da Costa Rica (Lei n 8.508, de 28 de abril de 2006).

122 Art. 36 e art. $95 \S 1^{\circ}$ da Ley de Regulación de la Jurisdicción de lo Contencioso-Administrativo da Nicaragua (Lei $\mathrm{n}^{\circ}$ 350, de 18 de maio de 2000).

123 Arts. 976-987 do Código de Processo Civil brasileiro (Lei n 13.105, de 16 de março de 2015).

124 PERLINGEIRO, Ricardo; SOMMERMANN, Karl-Peter. Euro-American Model Code of Administrative Jurisdiction: English, French, German, Italian, Portuguese and Spanish Versions. Niterói: Editora da UFF, 2014. p. 19. 
art. 57 do Código Modelo de Processos Administrativos (judicial e extrajudicial) para Ibero-América 125 .

De fato, demandas individuais com base em comportamentos administrativos de alcance geral, levam a uma das principais causas de demandas de igual teor (demandas repetitivas) na jurisdição administrativa: a exceção ao princípio da igualdade a que está sujeita a Administração Pública. ${ }^{126}$ Na medida em que uma decisão que envolva questão de interesse geral somente beneficiar o demandante individual, os demais cidadãos que se encontrarem na mesma situação fática sentir-se-ão, naturalmente, encorajados a ingressar com idêntica demanda judicial.

Contudo, em matéria de direito administrativo, não atende à noção de proporcionalidade permitir que a isonomia administrativa seja excepcionada pelas mãos dos tribunais judiciais 127 sob os fundamentos de que juízes têm liberdade para decidir diferentemente e de que partes litigantes têm o direito de buscar a melhor via procedimental para sustentar suas teses e pretensões. Tratando-se de uma questão de interesse geral, como fundamento de uma pretensão individual, sendo decidida por um juiz constitucionalmente legitimado, não seria compatível com o princípio do juiz natural que outro tribunal, posterior ou simultaneamente, decidisse a mesma questão, ainda que referente a partes litigantes distintas.

A propósito, o controle difuso de constitucionalidade ou de legalidade (em contraponto a um controle concentrado) não significa que a ordem jurídica deva tolerar decisões judiciais contraditórias. De fato, o controle difuso atribui jurisdição a todos os juízes, mas, uma vez que um deles seja escolhido (aleatoriamente) para decidir, deveria ser ele o juiz natural para aquele mesmo conflito, ainda que tal conflito voltasse a manifestar-se por outras vias procedimentais.

Nesse sentido,

[...] As normas processuais devem evitar que órgãos judiciais distintos tenham competência para conhecer de uma mesma causa, salvo quando as regras de litispendência forem capazes de impedir decisões conflitantes. A competência territorial e funcional dos órgãos judiciais deve considerar a natureza geral e individual dos atos impugnados,

\footnotetext{
125 GRINOVER, Ada Pellegrini; PERLINGEIRO, Ricardo et al. Código Modelo de Processos Administrativos - Judicial e Extrajudicial - para Iberoamérica. Revista Eletrônica de Direito Processual, Rio de Janeiro, v. X, p. 360-383. 2012.

126 Ver MORAES, Vânila Cardoso André de. A igualdade - formal e material - das demandas repetitivas sobre direitos sociais. Niterói, 2016. Tese (Doutorado)- Programa de Pós-graduação em Ciências Sociais e Jurídicas), Universidade Federal Fluminense; e MORAES, Vânila Cardoso André de. Demandas repetitivas sobre direitos sociais e a proposta do Código Modelo Euro-Americano para a realização da igualdade. In: MORAES, Vânila Cardoso André (Coord.). As demandas repetitivas e os grandes litigantes. Brasília: Enfam, 2016. p. 53-70.

127 PERLINGEIRO, Ricardo. O princípio da isonomia na tutela judicial individual e coletiva, e em outros meios de solução de conflitos, junto ao SUS e aos planos privados de saúde. Revista da Procuradoria-Geral do Município de Belo Horizonte - RPGMBH, Belo Horizonte, v. 5, n. 10, p. 217-227. 2012.
} 
bem como a extensão dos seus efeitos. [...] Constatada a existência de causas idênticas que contenham as mesmas partes, objeto e causa de pedir, transfere-se para o órgão judicial prevento a competência para o julgamento do processo iniciado posteriormente. Aplicam-se as regras anteriores, ainda que diante de demandantes distintos, às impugnações, por via direta, de um mesmo ato adminstrativo geral - abstrato e concreto - e às pretensões condenatórias, também por via direta, fundadas no mesmo interesse difuso ou coletivo. [...] Diante da possibilidade da decisão sobre a legalidade ou ilegalidade de ato administrativo geral, ou de sua interpretação, ou, ainda, de qualquer outro comportamento da administração, alcançar um número elevado de litígios, o órgão judicial deve suscitar uma questão correspondente perante aquele que decidiria por via direta a impugnação de ato administrativo geral, instaurando-se necessariamente um procedimento incidental, com suspensão do originário por prazo razoável ou até o advento de uma solução definitiva e erga omnes daquele incidente. [...].128 (grifo nosso)

Ademais, não se deveria confiar demasiadamente nas ações coletivas como alternativa às demandas individuais repetitivas na jurisdição administrativa. As ações coletivas, tipicamente de direito privado e com origem no common law, ${ }^{129}$ carecem de sensibilidade para questões de direito administrativo, especialmente quando dotadas do opt-in e opt-out. Por exemplo, a regra coisa julgada secundum eventum litis, do art. 33 do Código Modelo de Processo Coletivo para Ibero-América,130 não considera a frequente tensão entre interesses - nem sempre visível - nas causas de jurisdição administrativa cuja solução há de perseguir o interesse público predominante à luz do princípio da proporcionalidade.

$\mathrm{Na}$ verdade, as ações coletivas sequer seriam necessárias na jurisdição administrativa. Isso porque demandas individuais com base em comportamentos administrativos de alcance geral, na essência, são demandas que, se procedentes, trazem para a própria autoridade administrativa o dever - especialmente moral - de estender os efeitos favoráveis da sentença a todos os que se encontrarem na mesma situação fática. ${ }^{131}$ Entretanto, enquanto houver falhas nas regras de competência processual que

\footnotetext{
128 PERLINGEIRO, Ricardo et al. Princípios fundamentais e regras gerais da jurisdição administrativa Brasil-França-Espanha. Revista de Processo, Rio de Janeiro, v. 33, n. 163, p. 253-263. 2008. Sobre o "reenvio prejudicial de legalidade", ver o art. 20.1 do Código Modelo Euro-Americano de Jurisdição Administrativa (PERLINGEIRO, Ricardo; SOMMERMANN, Karl-Peter. Euro-American Model Code of Administrative Jurisdiction: English, French, German, Italian, Portuguese and Spanish Versions. Niterói: Editora da UFF, 2014. p. 12).

129 Ver REDISH, Martin H. Class Actions and the Democratic Difficulty: Rethinking the Intersection of Private Litigation and Public Goals. University Of Chicago Legal Forum. Chicago: University of Chicago, v. 2003, n. 1, Artigo 4, p. 71-139. 2003.

130 GRINOVER et al. Código Modelo de Processos coletivos para Ibero-América. São Paulo: Instituto Brasileiro de Direito Processual, 2004. p. 7, 20.

131 Ver PERLINGEIRO, Ricardo. O princípio da isonomia na tutela judicial individual e coletiva, e em outros meios de solução de conflitos, junto ao SUS e aos planos privados de saúde. Revista da Procuradoria-Geral do Município de Belo Horizonte - RPGMBH, Belo Horizonte, v. 5, n. 10, p. 217-227. 2012.
} 
permitam que mais de um juiz possa decidir a questão (de fundo), é compreensível que as autoridades administrativas resistam a tal dever de irradiar a terceiros interessados os efeitos de uma sentença, porque tais autoridades sentir-se-ão alimentadas com a esperança de obter, em outro processo, uma decisão judicial com tese contrária e a elas mais conveniente.

\section{DESAFIOS REFERENTES ÀS AUTORIDADES ADMINISTRATIVAS}

\subsection{Funções administrativas primárias}

Na América Latina, o princípio da legalidade administrativa continua sendo confundido com a legalidade estrita, isto é, a despeito da legislação vigente, 132 na prática, as autoridades administrativas não exercem um autocontrole da juridicidade constitucional e convencional de suas atuações, e não são capazes de proteger direitos fundamentais que desafiem a interpretação gramatical de leis. Isso ocorre basicamente por duas razões.

A uma, porque persiste na cultura jurídica latino-americana uma relação de subordinação entre Administração Pública e Governo, a qual acarreta o desprezo pelo requisito da capacidade técnica, em favor das indicações meramente políticas na escolha de funcionários públicos para ocuparem cargos-chave nas tomadas de decisão. A duas, porque prevalece na mentalidade dos funcionários públicos o dogma de que devem maior compromisso à subordinação hierárquica do que à legalidade, e muitos temem que, desafiando interpretações literais da lei, em favor de direitos fundamentais, possam ser acusados por desvio de conduta funcional.

Em consequência, as demandas relacionadas a certos deveres de prestação das autoridades que dependam da aplicação ou da interpretação de direitos fundamentais, escapam da margem de decisão das autoridades e, para terem alguma chance, precisam ser submetidas ao Judiciário. São demandas artificiais, porque sequer se encontram na esfera da discricionariedade das autoridades.

De fato, o requerimento administrativo prévio, como condição obrigatória para o ingresso com uma demanda judicial, 133 envolve direitos que, para serem postulados, dependem de fatos que estão em poder dos interessados e, enquanto tais fatos não são levados às autoridades, estas não têm o dever de prestação. Tal requerimento prévio,

132 Art. 9 (a) da Ley Argentina de Procedimiento Administrativo prevê o princípio da legalidade administrativa a partir de uma perspectiva da juridicidade. Da mesma forma, as leis da Costa Rica (art. 6 da Ley General de la Administración Pública de Costa Rica); do Peru (art. V 2.1 e 2.2 da Lei peruana de Procedimento Administrativo Geral); e da República Dominicana (art. 3.1 da Ley de Procedimiento Administrativo da República Dominicana). 133 Sobre o requerimento obrigatório prévio à demanda judicial, ver art. 30 da Ley Argentina de Procedimiento Administrativo. Sobre a distinção entre requerimento administrativo prévio e processo administrativo prévio, ver BRASIL. Supremo Tribunal Federal. Recurso Extraordinário 631.240/MG. Brasília, 3 de setembro de 2014. 
porém, será dispensado nos casos de medidas cautelares 134 e também substituído pelo ingresso direto de uma ação judicial, nos casos em que se sabe, desde logo, que a Administração negará o direito, como em uma pretensão contrária à interpretação ou na aplicação de lei consagrada por autoridade hierarquicamente superior a que estiver sendo instada a decidir.

A independência das autoridades administrativas para tomada de decisões necessita implicar prerrogativas para uma atuação livre que, dentro dos limites da competência administrativa, não se sujeite ao princípio da subordinação hierárquica. Tal princípio diz respeito apenas a poderes de disciplina, de estruturação da carreira (promoções e vantagens) e de organização do ingresso de novos funcionários.

Segundo a Corte I.D.H., ser independente, significa ser

autônomo em todas as ordens de seu desempenho jurisdicional, dotado das faculdades para resolver, sem ingerência de outros órgãos do Estado ou de qualquer outra instância, as lides que Ihe sejam submetidas. Essa autonomia deve existir tanto na norma que governa o desempenho judicial formal (Constituição e lei secundária), como na realidade na qual atua o julgador.135 (grifo nosso e tradução nossa)

Portanto, um funcionário público com atribuições decisórias não deve, no exercício de suas atividades, orientar-se por alguma motivação que não seja unicamente a decorrente da sua convicção técnica, o que, de fato, não impede que o campo da sua atuação decisória seja delimitado por regras claras de competência administrativa de modo a evitar a quebra da unidade da função administrativa.

\subsection{Funções administrativas secundárias}

A independência é igualmente necessária nas funções administrativas secundárias (funções de solução de conflitos pela própria Administração Pública) e, sendo pressuposto da imparcialidade, sua ausência implica sério comprometimento da imparcialidade objetiva, e descrédito generalizado do processo administrativo extrajudicial perante a sociedade. Em geral, é esse o quadro latino-americano.

Com isso, de um lado, estimulam-se os interessados que tenham direitos negados pela Administração a buscarem a sorte no Judiciário sempre que estiverem diante de uma resposta administrativa negativa em cujo acerto não confiem. De outro lado, justifica-se que leis processuais entreguem ao Judiciário o papel de longa manus da

\footnotetext{
134 Art. 33 do Código Modelo Euro-Americano de Jurisdição Administrativa (PERLINGEIRO, Ricardo; SOMMERMANN, Karl-Peter. Euro-American Model Code of Administrative Jurisdiction: English, French, German, Italian, Portuguese and Spanish Versions. Niterói: Editora da UFF, 2014. p. 15).

135 CORTE INTERAMERICANA DE DIREITOS HUMANOS. Caso Palamara Iribarne vs. Chile, São José, 22 de novembro de 2005. Voto em separado do Juiz Sergio García Ramírez na referida sentença; §9 (c).
} 
Administração para promover a execução judicial de decisões administrativas restritivas de direitos, como nas execuções de decisões tributárias, em flagrante contradição com o poder administrativo de autoexecutoriedade. ${ }^{136}$

A propósito, no Brasil, sempre houve resistência à proposta de que as autoridades promovessem a execução das suas próprias decisões, autorizando-as, por exemplo, a atos expropriatórios do patrimônio do devedor, sob o argumento de que as autoridades não estariam devidamente estruturadas para tanto. ${ }^{137}$ Na Argentina, a Corte Suprema de Justiça da Nação declarou inconstitucional, por ofensa ao princípio da separação de poderes, o art. 92 e seguintes da Lei de Procedimento Tributário de 1978 que permitia "ao agente fiscal penhorar fundos e valores do executado em contas bancárias".138

Lembre-se, também, das ações interpostas pelas autoridades para anular seus próprios atos administrativos que tenham gerado efeitos favoráveis aos particulares, como ocorre na Bolívia139, Costa Rica140, El Salvador141, Honduras142 e Paraguai143, o que é incompatível com o poder administrativo de autotutela, e ainda as ações de "improbidade administrativa" no Brasil, buscando junto ao Judiciário uma punição disciplinar e civil de funcionários públicos ímprobos, o que atesta a incapacidade das próprias autoridades exercerem o seu poder administrativo disciplinar.

\footnotetext{
136 Normas prevendo a execução fiscal em sede judicial: art. 653 do Código Orgánico Tributario da Venezuela (Decreto n 1.434, de 17 de novembro de 2014); Lei brasileira de Execução Fiscal (Lei ${ }^{\circ} 6.830$, de 22 de setembro de 1980). Contrariamente, admitindo a execução tributária pelas próprias autoridades, ver: arts. 98-101 Código colombiano Procedimiento Administrativo y de lo Contencioso Administrativo; art. 3 da Lei chilena de los Procedimientos Admnistrativos; art. 149 da Ley General de la Administración Pública de Costa Rica; art. 145 (1) do Código Federal Fiscal do México; art. 69 (1) do Código Tributário de la República Dominicana (Lei n 11, de 16 de maio de 1992).

137 Ver DUARTE, Fernanda. A execução é uma questão de justiça? Revista da Seção Judiciária do Rio de Janeiro, Rio de Janeiro, v. 12, n. 13, p. 45-58, mar. 2005; ERDELYI, Maria Fernanda. Proposta de execução fiscal da Fazenda é alvo de críticas. Consultor Jurídico, São Paulo, nov. 2007. Disponível em: < http://www.conjur. com.br/2007-nov-27/proposta_execucao_fazenda_alvo_criticas>. Acesso em: 31 jan. 2017; VASCONCELLOS, Marcos de. Ministros do STJ são contra execução fiscal sem juiz. Consultor Jurídico, São Paulo, jun. 2012. Disponível em: <http://www.conjur.com.br/2012-jun-08/ministros-stj-execucao-fiscal-administrativa-naufragar>. Acesso em: 31 jn. 2017; e BRANCO, José Denilson. Execução fiscal: possíveis soluções dentro da legislação vigente. In: MORAES, Vânila Cardoso André de (Coord.). As demandas repetitivas e os grandes litigantes. Brasília: Enfam, 2016. p. 71-96.
}

138 ARGENTINA. Corte Suprema de Justicia de la Nación Argentina. Case of Administracion federal de ingresos publicos c/ intercorp S.A. s/ ejecucion fiscal, Buenos Aires, 15 de junho de 2010.

139 O Tribunal Constitucional da Bolívia decidiu que "os atos administrativos que reconhecem direitos não podem ser suspensos em sede administrativa, a fim de assegurar sua estabilidade" (BOLIVIA. Tribunal Constitucional Plurinacional da Bolivia. Sentencia Constitucional Plurinacional 0584/2013. Exp: 02569-2013-06-AAC Santa Cruz, 21 de maio de 2013).

140 Art. 10.5 do Código Procesal do Contencioso-Administrativo da Costa Rica.

141 Arts. 7(b) e 8 da Ley de la Jurisdicción Contencioso-Administrativa de El Salvador.

142 Art. 15 da Ley de la Jurisdicción de lo Contencioso Administrativo de Honduras.

143 O Tribunal de Contas do Paraguai (Sentencia 280. Asunción, 18 de abril de 2002) afirmou a necessidade da ação judicial de nulidade sob o fundamento de que a controvérsia acerca do desfazimento de um ato administrativo favorável precisa ser decidida por um terceiro imparcial. 
Outra demonstração de que o processo administrativo extrajudicial não cumpre com o seu papel de solução de conflitos, e de que "não passa de uma tentativa de tirar água de um poço seco",144 é o fato de que as legislações de muitos países preveem o recurso administrativo como uma faculdade do interessado e não uma obrigatoriedade prévia ao ingresso de uma demanda nos tribunais. ${ }^{145}$ Nas raras leis em que o recurso administrativo é uma condição prévia para o acesso aos tribunais, 146 tal recurso, ainda assim, deve ser considerado uma faculdade do interessado sempre que houver risco de dano, admitindo-se que o interessado ingresse com uma medida (judicial) cautelar, mesmo que o processo administrativo (extrajudicial) não esteja concluído. ${ }^{147}$

Finalmente, deve-se ressaltar que a permissão para os tribunais judiciais exercerem uma jurisdição intensa sobre o conteúdo das decisões proferidas em processos administrativos extrajudiciais, na realidade, parte de uma premissa lógica de que a utilização de tais processos é mera faculdade a cargo dos cidadãos e das próprias autoridades, o que as torna, portanto, plenamente dispensáveis e substituíveis pela ação judiciária.

\section{CONTROLE DIFUSO DE CONVENCIONALIDADE PELAS AUTORI- DADES ADMINISTRATIVAS}

A incorporação pelos Estados latino-americanos da doutrina do controle difuso de convencionalidade establecida por la Corte I.D.H. é atualmente a peça chave para a concretização do dever das autoridades administrativas de proteger direitos fundamentais, ainda que, para tanto, seja necessário superar leis (inconstitucionais).

144 Cassagne destaca a decisão-paradigma da Sala Constitucional de La Corte Suprema de Justicia de San José de Costa Rica, no caso "Fonseca Ledesma”, em que o recurso administrativo prévio é equiparado a uma pretensão de "sacar água de um poço seco", na medida em que os órgãos superiores difícilmente alteram as decisões inferiores (CASSAGNE, Juan Carlos. El procedimiento administrativo y el aceso a la justicia. In: ABERASTURY, Pedro; BLANKE, Hermann-Josef (Ed.). Tendencias actuales del procedimiento administrativo en Latinoamérica y Europa. Buenos Aires: Universidad Buenos Aires, 2012. p. 75).

145 Súmula 89 do Superior Tribunal de Justiça brasileiro. Ver também art. 32 do Código Modelo Euro-Americano de Jurisdição Administrativa (PERLINGEIRO, Ricardo; SOMMERMANN, Karl-Peter. Euro-American Model Code of Administrative Jurisdiction: English, French, German, Italian, Portuguese and Spanish Versions. Niterói: Editora da UFF, 2014. p. 15).

146 Há exemplos de requerimento administrativo prévio como condição ao ingresso de uma ação judicial: de acordo com o art. 70 da Lei boliviana de procedimento administrativo, a tentativa prévia de solução de qualquer conflito administrativo é um pré-requisito para interposição da ação judicial. Também vale citar o art. 4.3 do Código de Justiça Administrativa da Federação Russa prevê a possibilidade do legislador, em certos casos, condicionar o acesso ao tribunal à conclusão do processo administrativo extrajudicial: "Quando em certas questões administrativas a lei federal impuser um prévio procedimento administrativo para a resolução de litígios administrativos ou outros conflitos de interesses públicos, o acesso aos tribunais será possível somente após o cumprimento de tais procedimentos".

147 Art. 23 (a) e 9 da Ley Argentina de Procedimiento Administrativo. Ver também o art. 32.3 do Código Modelo Euro-Americano de Jurisdição Administrativa (PERLINGEIRO, Ricardo; SOMMERMANN, Karl-Peter. Euro-American Model Code of Administrative Jurisdiction: English, French, German, Italian, Portuguese and Spanish Versions. Niterói: Editora da UFF, 2014. p. 15). 


\section{Segundo Mac-Gregor,}

A expressão controle de convencionalidade foi utilizada pela primeira vez pelo juiz García Ramírez em suas opiniões em separado em casos como Myrna Mack Chang v. Guatemala (que seguiu o precedente Barrios Altos). Ramírez entendeu que, em nível internacional, não é possível dividir o Estado, de modo a vincular a Corte I.D.H. apenas a um ou alguns dos seus órgãos, a conceder-Ihes representação do Estado no processo, sem que essa representação afete todo o Estado e exclua outros órgãos do regime de responsabilidade dos tratados, deixando suas ações fora do controle de convencionalidade que envolve a jurisdição do tribunal internacional. A ideia foi desenvolvida no precedente Tibi v. Equador: 'se os tribunais constitucionais supervisionam a constitucionalidade, o tribunal internacional de direitos humanos decide sobre a convencionalidade desses atos; e, finalmente, no precedente Vargas Areco v. Paraguai, que destacou que o controle de cumprimento '[é] a partir do confronto dos factos em causa e as disposições da Convenção Americana'. Mais tarde, o juiz Cançado Trindade também se referiu ao controle de convencionalidade como um mecanismo para a aplicação do direito internacional dos direitos humanos em nível nacional. 148 (grifo nosso)

A referida doutrina tinha inicialmente como destinatários todos os juízes nacionais, ${ }^{149}$ porém mais tarde ficou assentado que, no âmbito de sua competência, "todas as autoridades e órgãos de um Estado Parte da Convenção têm a obrigação de exercer um controle de convencionalidade".150

Segundo a Corte I.D.H.,

As obrigações convencionais dos Estados Parte vinculam todos os poderes e órgãos do Estado, o que significa que todos os poderes do Estado (Executivo, Legislativo e Judiciário ou outras esferas do poder público) e outras autoridades públicas ou estatais, de qualquer nível, incluindo seus mais altos tribunais de justiça, têm o dever de cumprir, de boa-fé, o direito internacional.151 (tradução nossa)

O dever de convencionalidade proposto pela Corte I.D.H. apresenta de quatro características: a) é exercido de ofício; b) sujeita-se a um bloco de convencionalidade,

\footnotetext{
148 Ver MAC-GREGOR, Eduardo Ferrer. The Constitutionalization of International Law in Latin American Conventionality Control: The New Doctrine of The Corte Interamericana de Direitos Humanos. American Society of International Law - AJIL Unbound, Washington, v. 109, p. 93-99. 2015. Avaible at: <https://www.asil.org/sites/ default/files/Ferrer\%20Mac-Gregor\%2C\%20Conventionality\%20Controlv3.pdf>.

149 CORTE INTERAMERICANA DE DIREITOS HUMANOS. Caso Cabrera García y Montiel Flores vs. Mexico, voto de Eduardo Ferrer Mac-Gregor Poisot, Juiz ad hoc. São José, 26 de novembro de 2010, § 33.

150 CORTE INTERAMERICANA DE DIREITOS HUMANOS. Caso de personas dominicanas y haitianas expulsadas vs. República Dominicana, São José, 28 de agosto de 2014, § 497.

151 CORTE INTERAMERICANA DE DIREITOS HUMANOS. La sentencia de supervisión del cumplimiento en el caso Gelman vs. Uruguay, São José, 20 de março de 2013, § 59.
} 
ou seja, trata-se de um controle limitado à interpretação das normas convencionais tal como formulado pela Corte I.D.H.;152 c) está a cargo de autoridades que devem exercer o referido controle com independência de sua hierarquia, grau, valor ou matéria de competência que a norma interna lhes outorgue; d) também está a cargo de autoridades administrativas e juízes, ainda que não tenham competência para o controle de constitucionalidade, o que não significa a opção pela norma ou jurisprudência convencional e a não aplicação da nacional. Trata-se apenas, e em primeiro lugar, tratar de harmonizar a norma interna com a convencional, através de uma interpretação convencional da norma nacional. ${ }^{153}$

Nesse ponto, explica a Corte I.D.H. que

em contrapartida, o grau de intensidade do controle difuso de convencionalidade irá reduzir-se naqueles sistemas onde não se permite o controle difuso de constitucionalidade e, por conseguinte, nem todos os juízes têm a faculdade de deixar de aplicar uma lei ao caso concreto. Nesses casos, é evidente que os juízes que carecem de tal competência exercerão o controle difuso de convencionalidade com menor intensidade, sem que isso signifique que não possam realizá-lo na medida de suas respectivas competências. Isso implica o fato de que não poderão deixar de aplicar a norma (ao não ter esse poder), devendo, em todo caso, realizar uma interpretação convencional da norma, ou seja, efetuar uma interpretação conforme não só à Constituição, como também à Convenção Americana e à jurisprudência convencional. Essa interpretação requer uma atividade criativa para se alcançar a compatibilidade da norma nacional conforme o parâmetro convencional e assim obter-se a efetividade do direito ou da liberdade de que se trate, com os maiores alcances possíveis em termos de princípio pro homine.154 (tradução nossa)

Contudo, no caso de absoluta incompatibilidade,

onde não exista interpretação convencional possível, se o juiz carece de faculdades para deixar de aplicar a norma, irá se limitar a assinalar a anti-convencionalidade da mesma ou, nesse caso, a semear a dúvida da inconvencionalidade diante de outros órgãos jurisdicionais competentes dentro do mesmo sistema jurídico nacional que podem exercer

\footnotetext{
152 Um bloco de convencionalidade, nos moldes da Corte I.D.H., não seria compatível com a jurisprudência constitucional de alguns países europeus. Acerca da supremacía constitucional em face das normas convencionais de direitos humanos, ver RÚSSIA. Tribunal Constitucional da Federação Russa (Конституционного Суда Российской Федерации), г. N 21-П, 14 de julho de 2015 (com referência aos precedentes dos tribunais constitucionais da Alemanha, Itália e Áustria).

153 Ver CORTE INTERAMERICANA DE DIREITOS HUMANOS. Caso Cabrera García y Montiel Flores vs. Mexico, voto em separado do Juiz Eduardo Ferrer Mac-Gregor Poisot, São José, 26 de novembro de 2010, § 33-35, 37, $42,44,59$.

154 Ver CORTE INTERAMERICANA DE DIREITOS HUMANOS. Caso Cabrera García y Montiel Flores vs. Mexico, voto em separado do Juiz Eduardo Ferrer Mac-Gregor Poisot, São José, 26 de novembro de 2010, § 37.
} 
o controle de convencionalidade com maior intensidade. Assim, os órgãos jurisdicionais de revisão terão que exercer dito controle e deixar de aplicar a norma ou declarar a sua invalidade por ser anti-convencional.155 (grifo nosso e tradução nossa)

No que concerne a um novo paradigma para o direito administrativo contemporâneo, anota Ernesto Jinesta que

[...] o controle de convencionalidade exercido pela jurisdição contencioso-administrativa amplia, ostensivamente, o parâmetro de legitimidade ao qual as condutas administrativas devem, substancialmente, adequar-se, o que provoca uma reorganização das fontes do direito administrativo, ao incorporar o bloco de convencionalidade como fator de contraste, e permite também vislumbrar um direito administrativo comum. 156 (grifo nosso e tradução nossa)

No México, a doutrina do controle difuso de convencionalidade é considerada a inspiração da modificação da Constituição, em 2011, cujo art. $1^{\circ}$ passou a dispor que todas as autoridades, no âmbito de suas competências, devem cumprir uma série de obrigações em matéria de direitos humanos. 157

Ademais, em harmonia com a jurisprudência da Corte I.D.H., a Suprema Corte de Justiça da Nação do México decidiu que

as autoridades administrativas não estão habilitadas a realizar nenhum tipo de controle constitucional, concentrado ou difuso, ou seja, não podem declarar a invalidade de determinado preceito e deixar e aplicá-lo, nem sequer sob o argumento de uma reparação de direitos humanos, já que isso implicaria, para interpor um meio de defesa, desatender os requisitos de procedência assinalados pelas leis, os quais devem ser cumpridos de maneira prévia a uma análise do mérito do assunto. Em todo caso, as disposições jurídicas, em sentido mais favorável às pessoas, devem ser interpretadas, sem que as autoridades administrativas descuidem das faculdades e funções que devem desempenhar em atenção ao âmbito de suas competências. Aceitar o contrário geraria incerteza jurídica em franca contravenção a outros direitos humanos como os de legalidade, devido processo e segurança jurídica, previstos nos artigos constitucionais 14 e 16.158 (tradução nossa)

\footnotetext{
155 Ver CORTE INTERAMERICANA DE DIREITOS HUMANOS. Caso Cabrera García y Montiel Flores vs. Mexico, voto em separado do Juiz Eduardo Ferrer Mac-Gregor Poisot, São José, 26 de novembro de 2010, § 39.

156 JINESTA, Ernesto. Control de convencionalidad difuso ejercido por la jurisdicción constitucional. Revista Peruana de Derecho Público, Lima, ano 16, n. 31, p. 47-57. 2015.

157 Art. 1 da Constitución Política de los Estados Unidos Mexicanos.

158 MÉXICO. SUPREMA Corte de Justicia de la Nación de México. Amparo directo en revisión 1640/2014, 13 de agosto de 2014.
} 
Também vale registrar que o Instituto Ibero-americano de Direito Processual, no Código Modelo de Processos Administrativos (Judicial e Extrajudicial) para Ibero-América, adotou a doutrina do controle difuso de convencionalidade ao prescrever que as autoridades administrativas, sempre que diante de leis inconstitucionais ou anti-convencionais, têm o dever de suscitar o incidente correspondente perante o tribunal judicial ou a autoridade administrativa competente. 159

\section{CERTAS PERSPECTIVAS ORGANIZACIONAIS PARA A JURIS- DIÇÃO ADMINISTRATIVA}

Na busca de um modelo de organização de jurisdição administrativa que considere as peculiaridades do sistema judiciário vigente na América Latina, duas questões merecem reflexões: a) garantias institucionais para as autoridades administrativas, nos limites das suas competências e no exercício de funções primárias executivas, que sejam orientadas pelo princípio da supremacia da lei, isto é, pela supremacia dos direitos fundamentais; b) uma jurisdição administrativa que, como função, seja independente não apenas no Judiciário, mas também que esteja a cargo da Administração.

A Corte Interamericana de Direitos Humanos entende que a cláusula da tutela judicial efetiva aplica-se aos tribunais e também às autoridades administrativas, e em dois níveis diferenciados: tratando-se de função materialmente jurisdicional exercida pelas próprias autoridades, ou seja, tratando-se de solução de conflito administrativo em caráter definitivo, e não sujeita à posterior revisão judicial, as autoridades públicas devem ser competentes, independentes, imparciais, previamente estabelecidas e atentas às garantias processuais 160 . Tratando-se, porém, de uma função meramente executiva da Administração Pública ou de uma atuação equiparável à função executiva, como a solução de conflitos que possa ser revista plenamente por um órgão judicial, as autoridades devem observar o art. 8 da Convenção Americana de Direitos Humanos apenas o suficiente para evitar uma decisão administrativa arbitrária161.

\footnotetext{
159 Art. 2, parágrafo único, do Código Modelo de Processos (Judicial e Extrajudicial) para Ibero-América (GRINOVER, Ada Pelegrini; PERLINGEIRO, Ricardo et al. Código Modelo de Processos Administrativos - Judicial e Extrajudicial - para Iberoamérica. Revista Eletrônica de Direito Processual, Rio de Janeiro, v. X, p. 360-383. 2012.

160 De acordo com a Corte I.D.H., "[...] a legislação deve assegurar que o funcionário autorizado pela lei para exercer funções jurisdicionais contemple as características de imparcialidade e independência que devem reger todo órgão responsável por determinar os direitos e as obrigações das pessoas [...]" (CORTE INTERAMERICANA DE DIREITOS HUMANOS. Caso Vélez Loor vs. Panama, São José, 23 de novembro de 2010, § 108, tradução nossa). Ademais, no caso Barbani Duarte y otros vs. Uruguay, a Corte I.D.H. trata o Tribunal do Contencioso Administrativo uruguaio como um tribunal materialmente jurisdicional, apesar de ser uma autoridade administrativa de resolução de litígios externa ao Poder Judiciário uruguaio.

161 CORTE INTERAMERICANA DE DIREITOS HUMANOS. Caso Claude-Reyes y otros vs. Chile, São José, 19 de setembro de 2006, $§ 118$ e 119 . No mesmo caso Claude-Reyes y otros vs. Chile, segundo a Corte I.D.H, decisão sem fundamentação é exemplo de uma decisão arbitrária (§ 120).
} 
Isso significa que, do ponto de vista dos direitos humanos, é discricionariedade política do legislador atribuir funções materialmente jurisdicionais às autoridades administrativas e sujeitá-las às mesmas exigências aplicáveis a tribunais judiciais, que, por consequência, teriam o seu campo de atuação proporcionalmente reduzido. Além disso, pode-se extrair da jurisprudência da Corte I.D.H. que as funções administrativas meramente executivas devem ser exercidas por autoridades que sejam - o quanto necessário - independentes e tecnicamente qualificadas para uma atuação administrativa que se subordine a fundamentais e não apenas à lei em sentido estrito.

\section{CONSIDERAÇÕES FINAIS}

Em uma América Latina que convive há mais de 200 anos com tribunais judiciais generalistas, discutir especialização de tribunais não parece a melhor opção a essa altura. Na verdade, o futuro da jurisdição administrativa latino-americana está na efetivação do devido processo legal na esfera administrativa (extrajudicial), tal como importado dos EUA nas últimas décadas, de modo a compensar o déficit de especialização em direito administrativo dos tribunais judiciais latino-americanos.

Ademais, a jurisprudência da Corte I.D.H., acerca do controle difuso de convencionalidade pelas autoridades administrativas nacionais, vai ao encontro da instituição de uma estrutura administrativa que, assemelhando-se à dos quasi judicial bodies or administrative tribunals de países vinculados ao common law, necessita de independência, imparcialidade e capacidade técnica para decidirem sob influência de normas constitucionais e normas convencionais de direitos humanos.

Em tal contexto, decisões administrativas devem sujeitar-se aos limites de regras de competência administrativa que

(1) considerem a distinção entre (1.1) interpretação conforme a Constituição e a Convenção Americana de Direitos Humanos e (1.2) declaração de inconstitucionalidade e de anti-convencionalidade por ação e omissão, e que

(2) também considerem o alcance do comportamento administrativo impugnado, para evitar insegurança com decisões contraditórias e facilitar a compreensão de que, enquanto vigente uma decisão administrativa favorável, seus efeitos devem irradiar-se para todos os que estiverem na mesma situação fática, ainda que não tenham sido demandantes.

Com efeito, o nível de especialização do Judiciário deve ser proporcional às habilidades das autoridades para cumprirem adequadamente o seu papel: quanto mais efetiva a atuação administrativa na proteção dos direitos fundamentais, maior a confiança 
dos cidadãos nas autoridades, maior a deferência judicial em favor das autoridades, e menor a necessidade do Judiciário e da sua especialização em direito administrativo.

De toda sorte, é fundamental que ocorram ajustes nas regras de competência processual judicial, de modo que não se sucedam decisões judiciais contraditórias sobre o mesmo comportamento administrativo, ainda que as partes litigantes sejam distintas.

Portanto, é mais do que oportuno tirar o foco do sistema judiciário e das leis processuais judiciais como únicos vilões da litigiosidade excessiva e na inefetividade da jurisdição administrativa. Ao contrário, a América Latina precisa assumir o seu sistema judiciário de jurisdição única, e reduzir progressivamente a competência dos tribunais judiciais em favor de uma reforma administrativa que, à luz da doutrina de controle difuso de convencionalidade consagrada pela jurisprudência da Corte Interamericana de Direitos Humanos, assegure atuações administrativas - executivas e jurisdicionais - sob a primazia dos direitos fundamentais.

Em outros termos, deve-se proceder a uma reforma que leve a Administração Pública a portar-se como um instrumento de manifestação do interesse público, e não mais com um ente para proteção de interesse político e financeiro próprios e ocasionais, com um fim sem si mesmo.

\section{REFERÊNCIAS}

ALVES, Clara da Mota S. Pimenta. Sistema brasileiro de precedentes: uma promessa não cumprida de redução da litigiosidade? In: MORAES, Vânila Cardoso André de (Coord.). As demandas repetitivas e os grandes litigantes. Brasília: Enfam, 2016.

ASIMOW, Michael. Five Models of Administrative Adjudication. American Journal of Comparative Law, Michigan, v. 63, n. 4, p. 3-32, setp./dec. 2015.

BEDAQUE, José Roberto dos Santos. Tutela cautelar e tutela antecipada: tutelas sumárias e de urgência. São Paulo: Malheiros, 1998.

BLANKE, Hermann-Josef. La función del procedimiento administrativo para el cumplimiento del mandato de ejecución, protección y concretización del derecho administrativo. Margenes de discrecionalidad y de apreciación. In: ABERASTURY, Pedro; BLANKE, Hermann-Josef (Ed.). Tendencias actuales del procedimiento administrativo en Latinoamérica y Europa. Buenos Aires: Universidad Buenos Aires, 2012.

BRANCO, José Denilson. Execução fiscal: possíveis soluções dentro da legislação vigente. In: MORAES, Vânila Cardoso André de (Coord.). As demandas repetitivas e os grandes litigantes. Brasília: Enfam, 2016.

BREWER-CARÍAS, Allan Randolph. Instituiciones políticas y constitucionales. Tomo VII: La justicia contencioso administrativo. Caracas: Editorial Juridica Venezolana, 1997. 
CANE, Peter. Administrative law. 5 ed. New York: Oxford University Press, 2011.

CARDOSO, Maurício. Brasil atinge a marca de 100 milhões de processos em tramitação na Justiça. Consultor Jurídico, São Paulo, set. 2015. Disponível em: <http://www.conjur.com.br/2015-set-15/ brasil-atinge-marca-100-milhoes-processos-tramitacao>. Acesso em: 31 jan 2017.

CASSAGNE, Juan Carlos. El procedimiento administrativo y el aceso a la justicia. In: ABERASTURY, Pedro; BLANKE, Hermann-Josef (Ed.). Tendencias actuales del procedimiento administrativo en Latinoamérica y Europa. Buenos Aires: Universidad Buenos Aires, 2012.

CATANHO, Lucas. Gasto com ações judiciais na Saúde cresce $400 \%$ em 5 anos: Despesa saltou de $\mathrm{R} \$ 3,7$ mi, em 2010, para R\$18,7 mi em 2015, na região de Ribeirão Preto; Estado acusa custo 'desnecessário'. A Cidade On Ribeirão Preto, Ribeirão Preto, maio. 2016. Disponível em: < https:// www.acidadeon.com/ribeiraopreto/cotidiano/cidades/NOT,2,2,1 169336,Gasto+com+acoes+judiciais+na+Saude+cresce+400+em+5+anos.aspx>. Acesso em: 31 jan. 2017.

CENTRO ELECTRÓNICO DE DOCUMENTACIÓN E INFORMACIÓN JUDICIAL DE HONDURAS. Unidad de Estadistica. Honduras, 2015.

CLARICH, Marcello. L'esecuzione. In: SANDULLI, Aldo (Ed.). Corso de Diritto Amministrativo: Diritto Processuale Amministrativo. n. 7. Milano: Giuffrè, 2013.

CLEMENTINO, Marco Bruno M. As demandas repetitivas de direito público e o princípio da procedimentalização da isonomia. In: MORAES, Vânila Cardoso André de (Coord.). As demandas repetitivas e os grandes litigantes. Brasília: Enfam, 2016.

CONSELHO NACIONAL DE JUSTIÇA. 100 maiores litigantes. Brasília: Departamento de Pesquisas Judiciárias, 2011.

CONSELHO NACIONAL DE JUSTIÇA. Justiça em números: ano base 2013. Brasília: CNJ, 2014.

CONSELHO NACIONAL DE JUSTIÇA. Justiça em números: ano base 2014. Brasília: CNJ, 2015.

CHASE PLATE, Luis Enrique. La justicia constitucional y la justicia administrativa. In: HERNÁNDEZ-MENDIBLE, Víctor (Coord.). Derecho administrativo iberoamericano. Tomo 2. Caracas: Ediciones Paredes, 2007.

CHITI, Mario Pilade. La tutela cautelare. In: CASSESE, Sabino (Ed.). Corso di dirittto amministrativo. n. 7. 2. ed. Milano: Giuffrè, 2013.

DIRECCIÓN GENERAL DE ESTADÍSTICAS JUDICIAL DE LOS ESTADOS UNIDOS MEXICANOS. Estadística Nacional - Anual 2014. México, 2014.

DUARTE, Fernanda. A execução é uma questão de justiça? Revista da Seção Judiciária do Rio de Janeiro, Rio de Janeiro, v. 12, n. 13, p. 45-58, mar. 2005.

ERDELYI, Maria Fernanda. Proposta de execução fiscal da Fazenda é alvo de críticas. Consultor Jurídico, São Paulo, nov. 2007. Disponível em: < http://www.conjur.com.br/2007-nov-27/proposta_execucao_fazenda_alvo_criticas>.Acesso em: 31 jan. 2017. 
FALCÃO, Joaquim. A bolha judicial. Revista Conjuntura Econômica, Rio de Janeiro, v. 60, n. 4, p. 45, abr. 2006.

FERNÁNDEZ RUIZ, J. Panorama general del derecho administrativo mexicano. In: GONZÁLEZ-VARAS IBÁÑEZ, Santiago (Coord.). El derecho administrativo iberoamericano. Granada: INAP, 2005.

FERNÁNDEZ TORRES, Juan Ramon. La pugna entre la Administración y los tribunales ordinarios como rasgo sobresaliente del primer constitucionalismo español. In: FERNÁNDEZ TORRES, Juan Ramon. Historia legal de la jurisdicción contencioso-administrativa:1845-1998. Madrid: lustel, 2007.

FROMONT, Michel. Droit administratif des États européens. Paris: PUF, 2006.

GRINOVER et al. Código Modelo de Processos coletivos para Ibero-América. São Paulo: Instituto Brasileiro de Direito Processual, 2004.

GRINOVER, Ada Pelegrini; PERLINGEIRO, Ricardo et al. Código Modelo de Processos Administrativos - Judicial e Extrajudicial - para Iberoamérica. Revista Eletrônica de Direito Processual, Rio de Janeiro, v. X, p. 360-383. 2012.

GUBERT, Jerson Moacir; BORDASCH, Rosane Wanner Silva. Processamento e Gestão das Ações de Massa. In: MORAES, Vânila Cardoso A. de (Coord.). As demandas repetitivas e os grandes litigantes. Brasília: Enfam, 2016.

GUERRA, Sérgio. Aperfeiçoando a regulação brasileira por agências: quais lições podem ser extraídas do sequiscentenário modelo norte-americano? In: . (Coord.). Teoria do Estado regulador. Curitiba: Juruá Editora, 2015.

HUAPAYA TAPIA, Ramón Alberto. Tratado del processo contencioso administrativo. Lima: Jurista Editores, 2006.

JINESTA, Ernesto. Control de convencionalidad difuso ejercido por la jurisdicción constitucional. Revista Peruana de Derecho Público, Lima, ano 16, n. 31, p. 47-57. 2015.

JINESTA, Ernesto. Principio general de la justiciabidad plenaria y universal de la conducta administrativa. In: BREWER-CARÍAS, Alan et al. (Coord.). La protección de los derechos frente al poder de la administración. Bogotá: Editoriales Temis, tirant lo Blanch y jurídica venezolana, 2014.

JORDÃO, Eduardo. Controle judicial de uma Administração Pública complexa: a experiência estrangeira na adaptação da intensidade do controle. São Paulo: Malheiros, 2016.

MAC-GREGOR, Eduardo Ferrer. The Constitutionalization of International Law in Latin American Conventionality Control: The New Doctrine of The Corte Interamericana de Direitos Humanos. American Society of International Law - AJIL Unbound, Washington, v. 109, p. 93-99. 2015. Avaible at: <https://www.asil.org/sites/default/files/Ferrer\%20Mac-Gregor\%2C\%20Conventionality\%20Controlv3.pdf $>$. 
MAIRAL, Héctor A. Control judicial de la Administración Pública. Buenos Aires: Depalma, 1984. MARGÁIN MANAUTOU, Emilio. De lo contencioso administrativo: de anulación o de ilegitimidade. México: Porrúa, 2009.

MAURER, Hartmut. Derecho administrativo alemán. Mexico: UNAM, 2012.

MAYER, Otto. Derecho administrativo alemán. Buenos Aires: Depalma, 1982.

MCKECHNIE, William Sharp. Magna Carta: A Commentary on the Great Charter of King John, with an Historical Introduction. Glasgow: Maclehose, 1914.

MORAES, Vânila Cardoso André de. A igualdade - formal e material - das demandas repetitivas sobre direitos sociais. Niterói, 2016. Tese (Doutorado)- Programa de Pós-graduação em Ciências Sociais e Jurídicas), Universidade Federal Fluminense.

MORAES, Vânila Cardoso André de. Demandas repetitivas sobre direitos sociais e a proposta do Código Modelo Euro-Americano para a realização da igualdade. In: MORAES, Vânila Cardoso André (Coord.). As demandas repetitivas e os grandes litigantes. Brasília: Enfam, 2016.

NOBRE JÚNIOR, Edilson Pereira. Direito administrativo contemporâneo. Salvador: Jus Podium, 2016.

ORGANIZAÇÃO DOS ESTADOS AMERICANOS. Lei Modelo Interamericana de Acesso à Informação Pública. AG/RES. 2607 (XL-0/10), 2010.

ÓRGANO JUDICIAL DE LA REPÚBLICA DE PANAMÁ. Estadísticas Judiciales, Ancón, 2011.

PERLINGEIRO, Ricardo et al. Princípios fundamentais e regras gerais da jurisdição administrativa Brasil-França-Espanha. Revista de Processo, Rio de Janeiro, v. 33, n. 163, p. 253-263. 2008.

PERLINGEIRO, Ricardo. A execução forçada de pretensões pecuniárias e a coerção administrativa de fazer, suportar ou omitir-se. Revista de Direito Administrativo Contemporâneo, São Paulo, v. 21, ano 3, p. 133-141. 2015.

PERLINGEIRO, Ricardo. O princípio da isonomia na tutela judicial individual e coletiva, e em outros meios de solução de conflitos, junto ao SUS e aos planos privados de saúde. Revista da Procuradoria-Geral do Município de Belo Horizonte-RPGMBH, Belo Horizonte, v. 5, n. 10, p. 217-227. 2012.

PERLINGEIRO, Ricardo. Uma perspectiva histórica da jurisdição administrativa na América Latina: tradição europeia-continental versus influência norte-americana. Revista de Investigações Constitucionais, Curitiba, v. 2, n. 1, p. 89-136, jan./abr. 2015.

PERLINGEIRO, Ricardo; SOMMERMANN, Karl-Peter. Euro-American Model Code of Administrative Jurisdiction: English, French, German, Italian, Portuguese and Spanish Versions. Niterói: Editora da UFF, 2014 
REDISH, Martin H. Class Actions and the Democratic Difficulty: Rethinking the Intersection of Private Litigation and Public Goals. University Of Chicago Legal Forum. Chicago: University of Chicago, v. 2003, n. 1, Artigo 4, p. 71-139. 2003.

REIS, Wanderlei José dos. Juiz-Gestor: um novo paradigma. Revista On Line do Instituto Brasileiro de Administração do Sistema Judiciário - IBRAJUS, [S.I.] 2011.

ROQUE, André Vasconcelos et al. O novo CPC e a desconfiança nos juízes. Jota, São Paulo, jun. 2015. Disponível em: <http://jota.info/artigos/o-novo-cpc-e-a-desconfianca-nos-juizes-15062015>. Acesso em: 31 jan 2017.

SIBERIAN LEGAL FORUM, 2, 2016, Tyumen. Administrative justice: comparative and Russian contexts. Rússia, 2016.

SILVA, Fábio de Souza. Discricionariedade técnica e direito à saúde: confiança como limite para o controle judicial. Niterói, 2014. Tese (Doutorado) - Programa de Pós-graduação em Sociologia e Direito, Universidade Federal Fluminense).

SILVEIRA NETO, Antônio. Conflitos de massa e gestão dos processos judiciais. In: MORAES, Vânila Cardoso A. de (Coord.). As demandas repetitivas e os grandes litigantes. Brasília: Enfam, 2016.

SOUZA, Giselle. Justiça determina novo arresto nas contas do governo do Rio de Janeiro. Consultor Jurídico, São Paulo, mai. 2016. Disponível em: < http://www.conjur.com.br/2016-mai-09/ justica-determina-arresto-contas-governo-rj>. Acesso em: 31 jan. 2017.

STRAUSS, Peter. An introduction to administrative justice in United States. Durham: Carolina Academic Press, 1989.

STRECK, Lenio Luiz. Juiz não é gestor nem gerente. Ele deve julgar. E bem! Consultor Jurídico, São Paulo, ago. 2013. Disponível em: < http://www.conjur.com.br/2013-ago-08/senso-incomum-juiz-nao-gestor-nem-gerente-juiz-julgar-bem>. Acesso em: 31 jan 2017.

TRIBUNAL DE LO CONTENCIOSO ADMINISTRATIVO DE LA REPUBLICA DE URUGUAY. Estadísticas, [S.I.], 2016.

VASCONCELLOS, Marcos de. Ministros do STJ são contra execução fiscal sem juiz. Consultor Jurídico, São Paulo, jun. 2012. Disponível em: <http://www.conjur.com.br/2012-jun-08/ministros-stj-execucao-fiscal-administrativa-naufragar>. Acesso em: 31 jan. 2017.

VERGARA BLANCO, Alejandro. Panorama general del derecho administrativo chileno. In: GONZÁLEZ-VARAS IBÁÑNEZ, Santiago (Coord.). El derecho administrativo iberoamericano. Granada: INAP, 2005.

WOLF, Hans J. et al. Direito Administrativo. v. 1. Lisboa: Fundação Calouste Gulbenkian, 2006.

ZILLER, Jacques. Administrations comparées: les systèmes político-administratifs de l'Éurope des Douze. Paris: Montchrestien, 1993. 